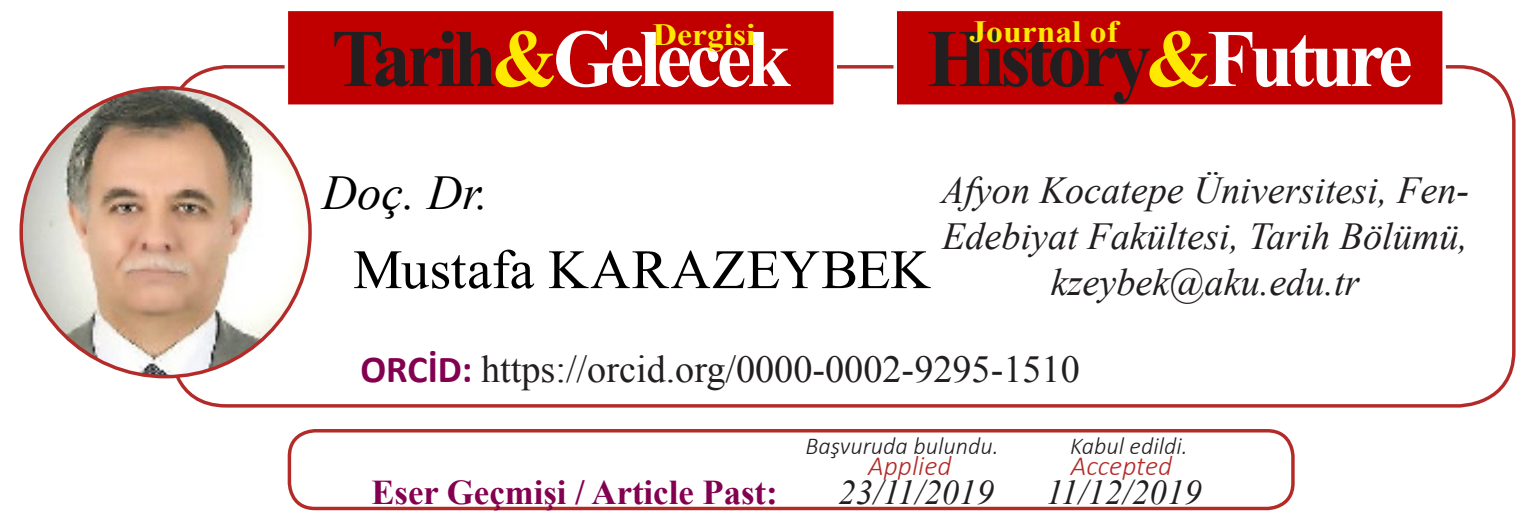

Araştırma Makalesi

DOI: http://dx.doi.org/10.21551/jhf.650273

Research Paper

Orjinal Makale / Orginal Paper

\title{
XIX. Yüzyılın Başından XX. Yüzyılın Başlarına Arap Coğrafyasinda Mevlevihaneler
}

\author{
Mevlevi Lodges in the Arab Land from 19th Century to the \\ Beginning of 20th Century
}

\section{$\ddot{\mathbf{O} z}$}

İslâm inancının muhtelif coğrafyalarda yayılmasıyla birlikte zamanla İslam toplumu içerisinde tasavvufí akımlar da ortaya çıkmaya başlamıştır. Bu tasavvufi akımlardan biri de Mevleviliktir. Mevlevilik, Mevlânâ Celâleddîn-i Rûmî'nin fikirleri ve ögretileri etrafinda şekillenen ve Anadolu'da 13. yüzyılda ortaya çı kmış bir tarikattır. Mevleviliğin usul âdâb ve kaidelerinin belirlenmesi ve bir tarikat olarak teşkilatlanması ise büyük ölçüde Mevlânâ'nın oğlu Sultan Veled ile başlamıştır. Mevlevilik, ortaya çıkmasından sonra bilhassa Anadolu'da, Balkanlarda ve Arap coğrafyasında önemli ölçüde yayılmıştır. Söz konusu bölgelerde birçok Mevlevihane açılarak Mevlânâ'nın fikirleri, hayat felsefesi ve ögretilerinin yaylması ve kalıcı olması sağlanmıştır. Arap Coğrafyasında Mevlevihânelerin açıllşsında Mevlânâ Celâleddîn-i Rûmî̀nin yedinci nesil torunlarından Afyonkarahisar Mevlevihanesi şeyhlerinden Semâ̂̀ Mehmet Çelebi'nin önemli katkıları olmuştur. Onun XVI. yüzyılda, Irak, Suriye ve Mısır'a yaptığ l seyahatler sonucunda muhtelif Mevlevihaneler açılmıştır. XVII. ve XVIII. yüzyıllarda da Arap coğrafyasında Mevlevihaneler açılmaya devam etmiştir. Bu süreçte, Bağdat, Kerkük, Musul, Şam, Şehrizor, Trablusşam, Halep, Hama, Humus, Kudüs, Lazkiye, Mekke, Medine ve Kahire gibi yerleşim yerlerinde Mevlevihaneler açılmuştır.

Anahtar Kelimeler: Mevlevilik, Mevlevihane, Mevlânâ, Arap coğrafyası, Tasavvuf.

\section{Abstract}

As Islamic faith spread in various lands, some sufistic strands in Islamic society began to appear. One of these sufistic strands is known as Mevleyiveh. Meyleviyeh is a dervish order, which essentially originated from the thoughts and doctrines of the Mevlana Celaleddin Rumi in the 13th century Anatolia. Defining Mevlevi's procedures, observances, rules and its organization as a dervish order mostly began with Mevlana's son Sultan Veled. Mevlevi sufism spread especially in Anatolia, Balkans and Arab Land to large extend after it appeared. Many Mevlevi lodges were opened in aforementioned regions in order to spread Mevlana's thoughts, philosophy and doctrine and provide them prolonged. Semai Mehmet Çelebi, who was the 7th descendant of Mevlana and one of the sheikhs of Afyonkarahisar Mevlevi Lodge, greatly contributed to the openings of new lodges in Arab Land. Various Mevlevi lodges were opened after his visits to Iraq, Syria and Egypt in the 16th century. Other Mevlevi lodges were opened successively in Arab region in the 17th and 18th centuries. In this process, Mevlevi lodges were opened in locations such as Baghdad, Kirkuk, Mosul, Domescus, Shahrizor, Tripoli, Aleppo, Hama, Homs, Jerusalem, Latakia, Mecca, Medina, Cairo and Algeria.

Keywords: Mevleviyeh, Mevlevi Chamber, Mevlana, Arab Land, Sufism

ATIF: KARAZEYBEK Mustafa, "XIX. Yüzyılın Başından XX. Yüzyılın Bașlarına Arap

Cografyasında Mevlevihaneler" Tarih ve Gelecek Dergisi, $5 / 3$ (Aralık-2019), s. (584-608)

CITE: KARAZEYBEK Mustafa, "Mevlevi Lodges in the Arab Land from 19th Century to the Beginning of 20th Century" Journal of History and Future, 5/3 (December- 2019), pp. (584-608) 


\section{Giriş}

oğolların Anadolu'da hakimiyetinin zayıflaması ile beylikler ortaya çımaya
başladı. Bu dönemde Mevlevilik Sultan Veled ve Ulu Arif Çelebi gibi şahsi-
yetlerin gayretleri ile yayılmaya başladı. Bilhassa Sultan Veled Mevleviliği
bir tarikat haline getiren ve sistemleşmeyi başlatan kişi oldu' ${ }^{1}$ Ulu Arif Çelebi
ise yanına aldığı dervişlerle birlikte Anadolu, İran, Suriye ve Mısır'da seyahatlar yaparak Mevleviliği tanıttı. Aynı zamanda gittiği yerlerde Mevlevihaneler açılmasını sağladı. Konya Mevlana Dergâhı Mevleviliğin yönetim merkezi oldu ve şeyhler merkez derganın şeyhinin teklifi ile padişahlar tarafından atand ${ }^{2}$. Büyük Mevlevihanelere, yani içinde çile çıkarılan, dede yetiştirilenlere "âsitane", diğerlerine "zâviye" adı verilirdi. Konya Mevlevihanesi ilk asitane olmakla birlikte merkez âsitâne konumunda idi .

Babasının ölümü üzerine Mevleviliği temsile başlayan Arif Çelebi, ömrünün önemli bir kısmını seyehatlerle geçirmiştir. Lârende, Beyşehir, Aksaray, Akşehir, Karahisar, Amasya, Niğde, Sivas, Tokat, Birgi, Denizli, Menteşe, Alaiye, Antakya, Bayburt, Erzurum, Irak, Tebriz, Merend ve Sultaniye'ye gitmiş, hemen hemen bütün Anadolu’yu gezmiş Irak ve Tebriz'e kadar uzanmıştır.

Mevlevihanelerin kurulmasında ve yayılmasında birinci derecede çelebiler etkili olmuştur. Mevlevihanelerin birçoğu doğrudan Çelebiler tarafından tesis edilir iken bir kısmı da onların görevlendirdiği kişiler tarafından açılmıştır ${ }^{5}$.

Afyonkarahisar Mevlevihanesi şeyhlerinden Sultan Divânî Mehmet Çelebi, Mevleviliğin yayılması ve birçok Mevlevihanenin açılmasında etkili olmuştur. Pîr Âdil Çelebi zamanında (14211460) Irak, Suriye ve Mısır'a kadar uzanan seyahatleri Arap coğrafyasında Mevleviliğin yayılmasına önemli katkı sağlamıştır. Mehmet Çelebi, Halep’te Ebubekir el-Vefâ̂̀’yi (Ölm. 1583) ve Mısır'da Ahmet Sâfî̀ yi halife yapmıştır. Veliyyüddin Baba'yı ise Mevlevi açmak üzere Cezayir'e göndermiştir. Halep, Burdur, Eğirdir, Sandıklı, Galata, Mısır, Cezayir, Midilli ve belki Lazkiye Mevlevihaneleri onun vasıtasıyla açılmıştır6.

Kuzey Suriye Mevlevihaneleri XVII. yüzyılda, çoğu kez yeniden tesis yoluyla ortaya çıkmıştır. Arap topraklarında Mevleviliğin yayılış ve istikrar kazanmasında XVII. yüzyılda, özellikle I. Ahmed ve IV. Mehmed dönemleri ön plana çıkar. Bu dönemde yerli eşraftan olmayıp dışarıdan gelen paşaların destekleri ile önemli ölçüde gelişme olmuştur ${ }^{7}$. Osmanlı paşalarının bunlarla gerek vakıf sahibi, gerekse himayeci olarak sıkı bir ilişki içinde bulundukları görülürr ${ }^{8}$.

Arap coğrafyasında açılan Mevlevihaneler aynı zamanda Osmanlı kültür ve medeniyetinin bölgede yayılması ve temsili görevini de üstlenmişlerdir ${ }^{9}$. Arap ülkeleri arasında Mevleviliğin en

1 Abdülbaki Gölpınarlı, Mevlânâ'dan Sonra Mevlevîlik (İstanbul: İnkılap ve Aka Kitapevleri, 1983), 12, 35 .

2 Mehmet Önder, “Konya'da Mevlânâ Dergâhı Merkez Arşivi ve Mevlevihaneler”, Osmanlı Araştırmaları 14, (1994): 138.

3 Yakup Şafak, "Konya Mevlâna Dergâhı Son Aşçıbaşısı Nizameddin Çelebi”, Curr Res Sci 3, no 2, (2017): 72.

4 Gölpınarlı, Mevlevîlik, 69.

5 Sezai Küçük, “Halep Mevlevîhânesi”, İLAM Araştırma Dergisi 3, no 2, (Temmuz-Aralık 1998): 75.

6 Gölpınarlı, Mevlevîlik, 110, 120-122.

7 Kraiser, "Mevlevihaneler", 104, 111.

8 Kraiser, "Mevlevihaneler", 112.

9 Sezai Kü̧̈ük, Mevleviliğin Son Yüzyılı (İstanbul: Vefa Yayınları, 2007), 314. 
çok rağbet gördügüü ülke Suriye olmuştur ${ }^{10}$.

Dergahlar tarikat mensuplarının faaliyet gösterdiği mekanlar olmasının yanı sıra gelip geçen misafirlere de hizmet veren konaklama yerleri idi. Bu yönüyle Şam'a seyahat eden ilim ve irfan sahibi kişiler, yolda Hama ve Humus Mevlevihanelerinde konaklayabilir, eğer güneye doğru iner ise Trablusşam ve Lazkiye Mevlevihanelerinde konaklayabilirdi ${ }^{11}$.

Suudi Arabistan ve Körfez ülkelerinde Mevlânâ’ya ilgi beklenen düzeyde olmamıştır. Bunun sebebi olarak söz konusu ülkelerde edebi ve kültürel birikimin zayıf olması gösterilmiştir ${ }^{12}$.

Yapılan bazı çalışmalarda Arap coğrafyasında bulunan 14 Mevlevihanenin ismi verilmektedir. Bunlar, Bağdat (Irak), Dımışk (Şam) (Suriye), Halep (Suriye), Hama (Suriye), Humus (Suriye), Kahire (Mısir), Kerkük (Irak), Kudüs (Filistin), Lazkiye (Suriye), Mavsil (Irak), Medine (Suudi Arabistan), Mekke (Suudi Arabistan), Şehrizor (Irak), Trablus (Libya) Mevlevihaneleridir ${ }^{13}$.

$\mathrm{Bu}$ çalışmanın amacı, Arap coğrafyasında faaliyet gösteren Mevlevihaneleri tespit ve tanıtmaktır. Bilhassa söz konusu Mevlevihaneler hakkında arşiv belgelerinde yer alan ve henüz literatüre geçmemiş olan verilere ulaşarak bunları meraklıların, araştırmacıların ve ilim erbabının bilgisine sunmaktır.

\section{Halep Mevlevihanesi}

Halep Mevlevihanesi, Şah İsmail ile Sultan Selim arasındaki savaş sırasında Osmanlı tarafina geçen Fulâd ve Alvân adlı iki İranlı mirza tarafından yaptırılmıştır. Söz konusu kişiler, Sultan Divani'nin İran gezisi sırasında Mevleviliği tanıyarak tarikata katılmışlar ve Halep'e yerleşerek burada bir Mevlevihane tesis etmişlerdir. İstekleri üzerine Konya'dan Kilisli Ahmed Fakri Dede buraya şeyh olarak gönderilmiştir. Ahmed Fakri Dede H. 950 (1543-4) yılından ölünceye kadar Halep'te şeyh olarak görev yapmıştır. Ondan sonraki şeyh büyük bir olasılıkla Mevlevi şair Ebu Bekir el-Vefâî'dir. H. 991'de (1583/84) vefat etmiş olup Halep'te gömülüdür ${ }^{14}$.

Evliya Çelebi tarafindan Halep Mevlevihanesi Konya'daki Mevlâna Türbesi ile eşdeğerde tutulmuştur. Bir bahçe içinde bina edilen bu tekkenin, dört tarafinın da hücrelerle çevrili olduğu kaydedilmiştir. Halep Mevlevîhanesinde Şeyh Bekrî isminde bir dervişin postnişîn olduğu ifade edilmiştir ${ }^{15}$.

Halep Mevlevihanesi'nde şeyhlik yapanlardan biri de Safîyullâh Mûsâ Dede>dir. 1708`de Halep Mevlevihanesi'nin başına geçmiştir. Evliya Çelebi, Halep'e vardığında, Mevlevihane camii yapım halindedir ${ }^{16}$.

Halep Mevlevihanesi hakkında arşiv kayıtlarında ulaştığımız belgeler XIX. yüzyılın sonları ve XX. yüzyılın başlarına aittir. Bu belgeler büyük ölçüde Mevlevihanenin şeyhliği ve şeyhler arasındaki şeyhlik mücadeleleri ile ilgilidir. Bunların önemli bir kısmı da Âmil Çelebi'nin şeyh olarak

10 Ahmet Kazım Ürün, "Ortadoğu'da Mevlâna ve Mevlevîhâneler”, Uluslar arası Sempozyum Dünyada Mevlâna İzleri, 13-15 Aralı 2007 Bildiriler içerisinde, Yayın ve Düzelti Kurulu: Nuri Şimşekler vd. (Konya: SÜMAM Yayınları, 2010), 448.

11 Küçük, Mevleviliğin Son Yüzyıll, 314-15.

12 Ürün, "Mevlevihaneler", 451.

13 Önder, "Mevlevihaneler", 141-42.

14 Kraiser, "Mevlevihaneler", 106-107.

15 M. Askeri Küçükkaya, "Evliya Çelebi Seyahatnamesi’nde Adı Geçen Mevlevihane ve Tekkeler", Harran Üniversitesi Illahiyat Fakültesi Dergisi 18, (Temmuz-Aralık 2007): 184.

16 Kraiser, "Mevlevihaneler", 103, 106. 
tayini veya şeylikten azliyle ilgilidir. Amil Çelebi’nin bu dönemde üç defa Halep Mevlevihanesine tayini söz konusu olmuş ve tayinler uzun tartışma ve yazışmalara sebebiyet vermiştir. Bu konuda ulaştığımız ilk belge Amil Çelebi'nin uygunsuz hareketleri olduğuna dair Ebubekir el-Vefâî Tekkesi postnişini Mustafa Muzaffer Dede’nin şikayeti sonucu ortaya çıkmıştır.

Mustafa Muzaffer Dede mühür ve imzası ile Sadarete gelen arzuhalin içeriği dikkate değer görülerek 30 Mart 1897 tarihli bir yazı ile Evkâf-1 Hümâyûn Nezâreti'ne havale edilmiş ve gereğinin yapılması istenmiştir ${ }^{17}$. Bunun üzerine durum Halep Vilâyeti'ne gizli bir şekilde bildirilmiştir. Gelen cevabi yazıya göre, Mustafa Muzaffer Dede adı geçen Mevlevi Tekkesi şeyhliği ve vakıf mütevelliliği nedeniyle Âmil Çelebi Efendi hakkında mahkemede açtığı davaları kaybetmiştir. Âmil Çelebi'nin şeyhliğe gelmesinden itibaren hangâhın gelirleri Muzaffer Dede'nin hırs ve hasedini uyandıracak bir şekilde artmıştır. Kendisine bir hisse çıkarmak isteyen Muzaffer Dede yaptığ 1 girişimlerden bir şey elde edememiştir. Çelebi aleyhindeki isnatlarının sebebi de budur. Sonuç itibariyle söz konusu arzuhalde dile getirilen iddiaların asılsız ve iftira niteliğinde olduğunun yapılan tahkikatta ortaya çıktığı bildirilmiştir. Evkâf-1 Hümâyûn Nezareti tarafından bu husus 7 Haziran 1897 tarihli bir üst yazı ile Sadarete takdim olunmuştur ${ }^{18}$.

Amil Çelebi, dergah şeyhliği döneminde Mevlevihane vakfına ait arsa üzerine dükkan ve mağaza yaptırmıştır. Ancak yaptırılan vakıf gayri menkulleri için belediye ile ruhsat alma hususunda problemler yaşanmıştır. Yapılmakta olan dükkan ve mağazalar için Belediye dairesi tarafından ruhsat istenmiştir. Dergâhın şeyhi Âmil Çelebi, bunun usule aykırı olduğunu ve vergiden muaf olması gerektiğini iddia etmiştir. Ancak Halep Vilâyeti'nden Dâhiliye Nezâreti'ne gelen 13 Ekim 1898 tarihli yazıda, Celâliyye vakıflarının muaf vakıflardan olmadı̆̆ yazı 9 Kasım 1898 tarihli yazı ile Dâhiliye Nezâreti'nden Evkâf-ı Hümâyûn Nezâreti'ne havale edilerek ne yapılması gerektiğinin bildirilmesi istenmiştir ${ }^{19}$.

11 Nisan 1899 tarihli Evkâf-ı Hümâyûn Nezâreti’nden gelen cevâbî yazıda, vakıf binalarının tamirat ve inşaatı için ruhsat alınması gerekmediği, belediyelere ruhsat ücreti olarak para ödenmemesi ve ödenmiş ise geriye ödenmesi gerektiğine dair Şurâ-yı Devlet kararı bulunduğu belirtilmiştir. Buna göre, gerek söz konusu dergâh akârâtının ve gerek bundan sonra inşa ve tamir edilmek istenilen diğer vakıf akârâtından ruhsat vergisi talep edilmemesi gerektiği belirtilmiştir. Bu husus 7 Mayıs 1899 tarihli yazı ile Dâhiliye Nezâreti'nden Halep Vilâyeti'ne bildirilmiş ve buna göre gereğinin yapılması istenmiştir ${ }^{20}$.

Bu gelişme üzerine Halep Vilâyeti'nden Dâhiliye Nezâreti'ne bir yazı gönderilmiştir. Yazıda, birtakım vakıf eserlerinin hayatiyetinin devamı için yapılan düzenlemenin aslen icâre-i vâhideli vakıf gelir kaynaklarının yapım ve onarımı için olduğu ifade edilmiştir. Şayet söz konusu düzenleme bütün vakıfları içine alacak şekilde uygulanacak olur ise zürriyete şart koşulan vakıflar da bundan faydalanabilecektir. Böylece karşılıksız ruhsat verilmesi sonucu ortaya çıkacak ve yasa vakıf eserlerinin korunmasına hizmet etmekten çıkacaktır. Sonuç olarak, sadece vakıf eserlerinin ayakta kalmasına hizmet edecek şekilde uygulamanın yapılması gerektiği ve diğer vakıfların vergi ödemesinin uygun olacağı mütalaasında bulunulmuştur. 8 Mart 1900 tarihli bu yazı 29 Mayıs 1900 tarihli bir üst yazı ile Dâhiliye Nezâreti'nden Evkâf-1 Hümâyûn Nezâreti'ne havale edilerek görüş istenmiştir. 4 Şubat 1901 tarihli Evkâf-1 Hümâyûn Nezâreti'nden Dâhiliye Nezâreti'ne gelen cevâbî yazıda, İstanbul ve sair yerlerde de aynı şekilde uygulama yapıldığı dile getirilmiştir. Aynı

17 Cumhurbaşkanlığı Devlet Arşivleri Başkanlığı Osmanlı Arşivi (COA.), BEO., 927/69508/1.

18 COA. BEO., 927/69508/2.

19 COA. DH.MKT., 2131/15.

20 COA. DH.MKT., 2198/93. 
zamanda, konuya ilişkin irade-i seniyyenin mutlak olduğu ve hiçbir değişiklik yapılmadığı için daha önce belirtildiği şekilde uygulama yapılması gerektiği bildirilmiştir. Dâhiliye Nezâreti de gelen bu yazıyı 6 Mart 1901 tarihli yazı ile Sadarete havale ederek, vakıf eserlerinin hayatiyetini sürdürebilmesini sağlamak amacıyla çıkarılan vergiden muafiyet iradesinden zürrî vakıfların da istifade etmesi nedeniyle amacından saptığı yönündeki mütalaaları dile getirerek konunun Şûrâ-yı Devlet'çe yeniden tetkik ettirilmesi gerektiği arz edilmiştir ${ }^{21}$. Bu mesele ile alakalı bir gelişme olup-olmadığ hakkında ise bir bilgiye ulaşılamamıştır. Ancak Mevlevihanenin vakıflarıyla alakalı, bilhassa vakıf arsasını satma meselesi onun hakkındaki şikayetler içerisinde önemli bir yer tutmuştur.

Amil Çelebi hakkındaki önceki şikayetler daha sonra da devam etmiştir. Bu defa şikayet Derviş Salih ve arkadaşları tarafindan gerçekleşmiştir. Halep merkezinden çekilen telgrafname ile Halep Mevlevi Şeyhi Âmil Çelebi Efendi'nin vakıf gelirlerine zarar vermekte olduğu bildirilmiştir. Bu ihbara dayalı olarak Halep Vilâyeti'nden durum sorulmuştur. Cevaben gelen ve Şeyhülislamlığa havale edilen 9 Ocak 1906 tarihli telgrafnamede, Derviş Salih'in rezil bir şahıs olduğu ve daha önce de Şeyhülislamlık'tan gelen talimatla hakkında yapılan tahkikat neticesinde Âmil Çelebi hakkındaki şikayetlerin asılsız olduğunun açığa çıktı̆̆ beyan edilmiştir. Aynı zamanda şikayeti tertipleyen ve kötü hali Halep'te bilinen Rifâi Şeyhi Mahmud Efendi'nin Âmil Efendi'den 85 lira talep ettiği ve bu parayı vermesi halinde iddia ve şikayetten vazgeçeceğini pervasızca dile getirdiği belirtilmiştir. Bununla birlikte dergâh vakfına dikkate değer bir şekilde hizmet edildiği belirtilerek Âmil Efendi'nin söz konusu şikayet üzerine azlinin uygun olmadığı dile getirilmiştir. Sadaret'ten Şeyhülislamlık'a gönderilen 11 Ocak 1906 tarihli yazıda, daha önce Çelebi Efendi tarafindan gerçekleşen bildirim üzerine Âmil Çelebi Efendi azil edilmiş iken Şeyhülislamlığa olan sadakatinden dolayı tekrar memuriyetinde bırakılmış olması ve hâl-i hazırda kendisinin azli ile mağduriyetinin padişah tarafından uygun görülmeyeceği dikkate alınarak gereğinin yapılması istenmiştirir ${ }^{22}$.

Her ne kadar Amil Çelebiınin görevden alınmaması, yapılan şikayet ve ihbarların asılsız veya yalan olduğuna ilişkin mahallinden yazılar gelmiş olsa da, bir süre sonra görevden alındığı yapılan bazı yazışmalardan ortaya çıkmaktadır. Bu yazışmaların birine göre, hakkındaki şikayete binaen azil edilmiş olan Âmil Çelebi’nin yerine bu husustaki Şeyhülislamlık makamının görüşü gereğince Said Çelebi (Sadettin Çelebi olmalıdır) tayin edilerek gönderilmiştir. Ancak mahallince Âmil Çelebi işten el çektirilmemiştir. Mevlevihane şeyhliği ve vakfın idaresinin Said Çelebi'ye teslimden kaçınıldığı anlaşılmıştır. Bunun üzerine, Sadaretten Şeyhülislamlığa 30 Ocak 1906 tarihli yeni bir yazı gönderilmiştir. Bu yazıya, Çelebi Efendi'den gelen ve kendisinin şeyhliğe devamının caiz olmadığına dair bazı ifadeleri içeren bir evrak da ek olarak konularak Şeyhülislamlık'tan gereğinin yapılması istenmiştii ${ }^{23}$.

Daha sonraki yazışmalardan Amil Çelebi'nin yeniden şeyh tayin edildiği anlaşılmaktadır. Âmil Çelebi Efendi'nin Halep Mevlevihanesi Şeyhliği'ne iade edilmesi üzerine yedi ay önce söz konusu şeyhliğe tayin edilen Sadettin Çelebi Efendi boşta kalarak geçimini sağlamakta s1kıntı çekmeye başlamıştır. Halep Vilâyet Meclisi 8 Eylül 1906 tarihli bir mazbata düzenleyerek Şeyhülislamlığa göndermiştir. Bu mazbatada, Sadettin Çelebi'nin Dedesi Aşçıbaşı Nesib Dede Efendi'ye Abdülmecid Han tarafından ihsan edilen, sonra babası Vacid Çelebi'ye intikal eden ve onun vefatıyla da hazineye kalan aylık bin kuruş maaşın Sadettin Çelebi'ye tahsisini talep etmiştir $^{24}$. Konya Mevlânâ Dergâhı postnişini Abdülvâhid Çelebi de Şeyhülislamığa gönderdiği 20 Eylül

21 COA. DH.MKT., 2352/31, 2458/25.

22 COA. BEO., 2739/205354.

23 COA. BEO., 2753/206453.

24 COA. BEO., 2982/223641/4. 
1906 tarihli arzuhaline Halep Vilayeti mazbatasını ek olarak sunarak, Halep Mevlevihanesi eski şeyhi Sadettin Çelebi'nin mağdur ve perişan halinden bahsederek, babası Vacid Çelebi'den kalan bin kuruş maaşın tahsis edilmesini istemiştir ${ }^{25}$. Halep Vilâyeti'nden sadarete gelen yazı üzerine Sadaret'ten Maliye Nezareti'ne gönderilen 30 Eylül 1906 tarihli yazı ile Vacid Dede'nin vefat tarihinin, vefatından sonra maaşının başkasına tahsis edilip edilmediğinin ve talepte bulunan Sadettin Çelebi'nin başka maaşının olup olmadığının, var ise miktarının bildirilmesi ve eklerin de iadesi talep edilmiştir ${ }^{26}$. Bu arada konu, Şeyhülislam Mehmet Camalettin Efendi'nin imzası ile Meşihat makamından 7 Ekim 1906 tarihli bir yazı ile Sadaret makamına arz edilmiştir. Konya Mevlânâ Dergâhı postnişininin yazısı ile Halep Vilâyeti İdare Meclisi'nin mazbatası da ek olarak gönderilerek, babası Vacid Çelebi'ye ödenen ve vefatıyla kesilen aylık bin kuruş maaşın Sadettin Çelebi'ye tahsisi talep edilmiştir ${ }^{27}$. Sadaret'ten Maliye Nezareti'ne gönderilen 10 Ekim 1906 tarihli yazıda, Vacid Çelebi Efendi'den boşalan bin kuruş maaşın tahsisi hakkında hazine tarafından malumat ve mütalaanın bildirilmesi istenmiştir ${ }^{28}$.

Maliye Nezareti'nden, verilen cevapta söz konusu maaşla ilgili teferruatlı bilgi verilmiştir. Bu maaş, Konya Dergâhı postnişini Çelebi Efendi'nin eniştesi Halep Mevlevihanesi Şeyhliği'nden ayrılan Hüseyin Vâcid Dede Efendi'ye diğer bir meşihate tayin oluncaya kadar Konya Sancağı gelirlerinden geçici olarak aylık bin kuruş muhtâcîn maaşı olarak tahsis olunmuştur. Vacid Dede'nin 24 Mart 1896 tarihinde vefatı nedeniyle maaş kaydı silinmiş ve para da o dönemde tahsisi emredilen diğer maaşlara karşılık tutulmuştur. Diğer taraftan Sadettin Çelebi adına Konya Sancağı'nda maaş kaydının olmadığı 16 Ocak 1907 tarihli yazı ile Sadarete bildirilmiştir ${ }^{29}$. Nihayetinde bütün yazışmalar Sadarette toplanmış ve durum özetlenerek 20 Ocak 1907 tarihli yazı ile meşihat makamina bildirilmiştir ${ }^{30}$.

Amil Çelebi, Meşrutiyetin ilanını müteakip ahaliden gördüğü baskı üzerine firara mecbur kaldığ $^{11}$ ve yerine Sadeddin Efendi'nin tayin olunduğu anlaş1lmaktadır ${ }^{32}$. Ancak daha sonra Âmil Çelebi, iyi hizmetleri olduğu gerekçesiyle söz konusu şeyhliğe yeniden tayin olunmuştur. Buna karş111k, önceki şeyh Sadettin Efendi dergâhı terk etmek istememiştir. Sadettin Efendi'nin şeyhlikten alakasını kesmesi için Halep Vilayeti aracılığı ile kendisine gerekli emrin gönderilmesine dair Veled Çelebi 29 Mart 1911 tarihinde hem Evkâf Nezâreti'ne hem de Sadarete telgraf göndermiştir ${ }^{33}$. Sadaret, 1 Nisan 1911 tarihli bir üst yazı ile söz konusu telgraf ile aynı konuda gelen diğer telgrafları şeyhülislamlığa havale ederek gönderilen evrakın muhtevasına ilişkin mütalaa istemiştir ${ }^{34}$. Diğer taraftan Dâhiliye Nezâreti de 2 Nisan 1911 tarihinde Halep Vilâyeti'ne bir yazı göndermiştir. Bu yazıda, Amil Çelebi'nin Halep Mevlevi Şeyhliği’ne iadeten tayin olunduğu halde önceki şeyh Sadeddin Efendi'nin dergâhı terk ve teslimden imtina ettiğinin Veled Çelebi tarafından bildirildiğini ifade ederek, Amil Çelebi’nin görevden alınması ve Sadeddin Efendi'nin karşı

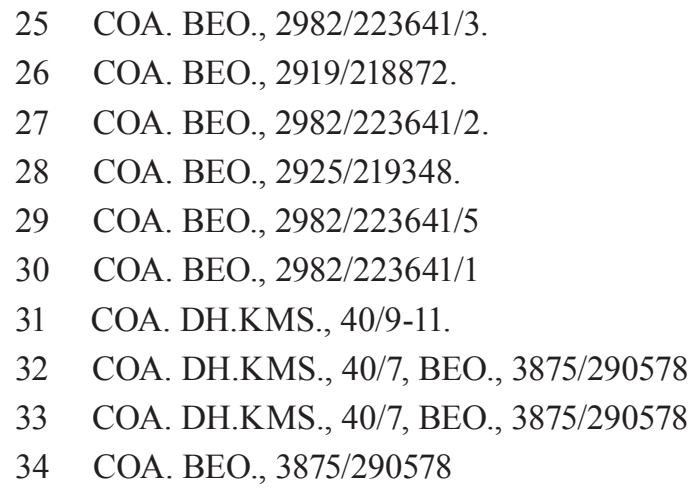


çıkma sebebinin araştırılarak bildirilmesini istemiştir ${ }^{35}$.

4 Nisan 1911 tarihli Halep Valisi Hüseyin Kazım'dan gelen cevabi yazıya göre, Amil Çelebi kötü ahlakı ile meşhurdur. Meşrutiyet'in ilanını müteakip ahaliden gördüğ̈̈ baskı üzerine firara mecbur kalmıştır. Halep Mevlevi meşihatine tayini bütün halk nezdinde iyi karşılanmamıştır. Diğer taraftan, Veled Çelebi kendisine bir telgraf göndererek Amil Çelebi'nin şeyhliğe tayinini bildirmiştir. Amil Çelebi kendisi görev yerine gelmeyerek Kilis Mevlevi Şeyhini vekaleten Halep'e göndermiş̧ir. Ancak Sadeddin Efendi vakfı bırakmak istememiştir. Vali aynı zamanda meselenin aslının, tarafların Mevlevihanenin gelirlerini ele geçirme mücadelesinden ibaret olduğu kanaatini de dile getirmiştir. Vali, Amil Çelebi hakkındaki muhtelif olumsuz olaylardan da bahsederek böyle bir kişinin tekrar göreve iade edilmesini mantıksız olarak nitelemiştir ${ }^{36}$.

Halep Mevlevihanesi Postnişini sıfatıyla Sadeddin Efendi de 14 Ekim 1913 tarihinde Dâhiliye Nezâreti'ne bir telgraf göndermiştir. Bu yazıda, türlü haklı şikayetler sonucunda Halep Mevlevihanesi Şeyhliği’nden alınan Amil Çelebi'nin iki yıl önce de yanıltıcı bilgiler ile göreve iade kararının alındığını, ancak sonunda mağduriyetinin anlaşıldığını ifade etmiştir. Bu defa da görevden alınmasını gerektiren olumsuz bir durumun olmamasına rağmen Amil Çelebi'nin göreve iade haberinin duyulduğunu dile getirilerek bunun kanuna aykırı olduğunu belirtilerek mağdur edilmemesini arz etmiştir ${ }^{37}$.

Mevlevihanedeki dervişlerden bir kısmı, Sadeddin Efendi'den memnuniyetlerini belirterek, Amil Çelebi'nin tekke kapısından girmesine müsaade etmeyeceklerini ifade etmişlerdir ${ }^{38}$. Diğer bir kısmı da Amil Çelebi'yi destekleyerek aleyhindeki şikayetlere itibar edilmemesini istemişlerdir ${ }^{39}$.

Amil Çelebi ve Sadeddin Efendi lehinde ve aleyhinde dervişler ve ahaliden muhtelif kişilerin şikayet ve arzları devam eder iken Vali Celal Efendi, 19 Ekim 1913 tarihli gönderdiği şifre telgrafta, Amil Çelebi'ye umumun ve dervişlerin ekseriyetinin karşı olduğunu, Sadeddin Efendi'nin de görevde kalmasının uygun olmayacağını belirtilerek başka birinin tayin edilmesinin uygun olacağı$\mathrm{n} 1$ arz etmiştir ${ }^{40}$. Lehte ve aleyhte yazışmalar devam eder iken Vali Celal Efendi 12 Ekim 1913 tarihinde yeni bir şifreli telgraf daha göndermiştir. Bu telgrafta, Amil Çelebi'nin Halep Mevlevihanesi postnişinliğine tayin edildiğine dair Meşihat makamından resmi yazının kendisine ulaştığı, Amil Çelebi’nin de Şam'a ulaştı̆̆ 1 ve iki güne kadar Halep'e geleceğinin anlaşıldığı ifade edilmiştir. Aynı zamanda, bu haber duyulur duyulmaz umumda nefret uyandığı, tekkenin boşaltılarak kendisine teslimin de mümkün olmayacağını zannettiğini dile getirmiştir. Sonunda, Sadeddin Efendi'nin azli gerekli ise yerine Amil Çelebi haricinde birinin gönderilmemesini talep etmiştir ${ }^{41}$.

Bunun üzerine 13 Ekim 1913 tarihinde Dâhiliye Nezâreti'nden Konya Vilayeti’ne bir yazı gönderilerek bakanlıktan yeni bir yazı gelmedikçe Amil Çelebi'nin göreve başlatılmaması emredilmiştir. Ayn zamanda Halep’ten konuyla ilgili gelen telgrafların da Veled Çelebi'ye tebliğ edilmesi istenmiştir ${ }^{42}$.

Dâhiliye Nezâreti’nden Konya Vilâyeti’ne gönderilen 19 Ekim 1913 tarihli yazı ile nihayet
35 COA. DH.KMS., 40/5.
36 COA. DH.KMS., 40/9-11.
37 COA. DH.KMS., 40/13.
38 COA. DH.KMS., 40/15-16.
39 COA. DH.KMS., 40/18.
40 COA. DH.KMS., 40/24.
41 COA. DH.KMS., 40/54.
42 COA. DH.KMS., 40/57, 60. 
valinin daha önce teklif ettiği çözüme itibar edilerek Amil Çelebi ve Sadeddin Efendi'nin tayinlerinden vazgeçilerek yerlerine muhterem bir zatın tayin edilmesi ve neticenin bildirilmesi istenmiştir ${ }^{43}$. Halep Heyet-i Merkeziyyesi de Amil Çelebi’nin tayinine karşı çıkarak kabiliyetli birinin tayinini istemişlerdir ${ }^{44}$.

Konya Valisi Hüsnü Efendi meselenin çözümüne ilişkin olarak Veled Çelebi’ye, Amil Çelebi'nin Kastamonu'ya ve Kastamonu'da bulunan Ahmet Remzi Dede'nin de Haleb'e naklini teklif etmiştir. Veled Çelebi'nin bu teklifin uygun olacağını belirtmesi üzerine durumu 20 Ekim 1913 tarihli bir yazı ile devlet merkezine bildirmiştir ${ }^{45}$. Dâhiliye Nezâreti'nden 21 Ekim 1913 tarihinde Konya vilayetine bir yazı gönderilerek söz konusu yer değişikliğinin uygun görüldüğü bildirilmiştir $^{46}$. Buna rağmen, Amil Çelebi ve destekçilerinin durumu oldubittiye getirerek gerçeğe aykırı beyanlar ile görevi devraldığı ve meselenin ortadan kalktığına dair girişimleri olmuştur. Buna karşılık Halep Valisi verilen bilgilerin yalan olduğunu bildirmesi ile Dâhiliye Nezareti'nden Konya Vilayeti'ne 28 Ekim 1913 tarihinde yeni bir yazı gönderilerek daha önce verilen karar doğrultusunda Amil Çelebi'nin Kastamonu'ya ve Kastamonu şeyhinin de Halep'e tayininin tamamlanması istenmiştir ${ }^{47}$. Amil Çelebi Dahiliye Nazırı Talat Bey’e gönderdiği 29 Ekim 1913 tarihli telgrafla azledilmiş olan Şeyh Sadeddin Dede'nin dergâhı teslim etmediğini ve görevini yerine getirmesine engel olmak için halkı ifsad ettiğini ifade ederek yardımını istemiştir ${ }^{48}$. Buna rağmen, nihayet Halep Mevlevihanesi Şeyhi Sadeddin Dede'nin azline, Amil Çelebi'nin Kastamonu Mevlevihanesi Şeyhliği’ne dair Veled Çelebi Efendi'nin iki mektubu söz konusu kişilere gönderilmiştir. Aynı zamanda, Halep Mevlevihanesi Şeyhliği'ne de Kastamonu Mevlevihanesi Şeyhi Remzi Dede'nin tayin edildiğine dair mektup da Kastamonu Vilâyeti'ne gönderilmiştir. Diğer taraftan bu tayinler 3 Kasım 1913 tarihli birer yazı ile Halep Vilayeti, Kastamonu Vilayeti ve Konya Vilayeti'ne gönderilmiştir ${ }^{49}$. Şeyhlik meselesi de böylece çözüme kavuşmuştur.

Türkiye'de tekke ve zaviyelerin kapatılmasından sonra Celaleddin Bakır Çelebi, Çelebilik makamını Halep`e taşımıştır. Bu tarihten itibaren Halep Mevlevihanesi, Mevlevihanelerin yönetimi hususunda ayrı bir misyon yüklenmiştir ${ }^{50}$. Bâkır Çelebi'nin hayatını kaybetmesinin ardından Mevlevihaneye Evkaf Umum Müdürlüğü tarafindan el konularak muhiblerden bir Arap şeyh vekili tayin edilmiştir ${ }^{51}$.

Halep Mevlevihanesi Şeyhleri: Fakrî Ahmed Dede (ö.994/1585), Hasan Dede (ö.1065/1654), Hüseyin Dede (ö.1120/1708), Şâtır Mehmed Dede (ö.1705'ten önce), Şekib Ömer Dede (ö.1135/1722), Sâfî Mûsâ Dede (ö.1157/1744), Muhammed Dede (ö.1144/1731), Hasan Dede (ö.1172/1758), Mustafa Dede (ö.1187/1773), Muhammed Ali Dede(ö.1219/1804), Abdülganî Dede (ö.1298/1880), Vâcid Dede (ö.1309/1891-1892), Âmil Çelebi (ö.1920), Muhammed Sa'deddin Dede (ö.?) ve Ahmed Remzi Dede (Akyürek) (ö.1944) ${ }^{52}$.

$\begin{array}{ll}43 & \text { COA. DH.KMS., 40/65. } \\ 44 & \text { COA. DH.KMS., 40/67. } \\ 45 & \text { COA. DH.KMS., 40/74. } \\ 46 & \text { COA. DH.KMS., 40/72. } \\ 47 & \text { COA. DH.KMS., 40/79-94. } \\ 48 & \text { COA. DH.KMS., 40/101. } \\ 49 & \text { COA. DH.KMS., 40/99, 103. } \\ 50 & \text { Ürün, "Mevlevihaneler”, 449. } \\ 51 & \text { Gölpınarlı, Mevlevîlik, 363. } \\ 52 & \text { Küçük, «Halep Mevlevîhânesi”, 78-90. }\end{array}$




\section{Şeyh Ebubekir el-Vefâî Dergâhı}

Sadaret Mektubi Kalemi'nden Evkâf-1 Hümâyûn Nezâreti'ne gönderilen 30 Mart 1897 tarihli bir yazıda «Halep Mevlevi Tekkesi postnişîni Âmil Efendi'nin harekât-ı gayr-i lâyıka ve ahvâl-i nâ-becâsından bahisle ba'zı ifâdeyi hâvî Ebûbekir el-Vefầî Tekkesi postnişîni Mustafa Muzaffer Dede mühür ve imzâsıyla gönderilen arzuhâl ..."53 şeklinde bir ifade bulunmaktadır. Bu ifadeden, Halep Mevlevihanesi haricinde Halep'te Ebûbekir el-Vefầ î Tekkesi ismiyle ayrı bir Mevlevi tekkesinin varlığı anlaşılmaktadır. Ancak bu ismin "Halep Mevlevihanesi" için kullanılan diğer bir isim olma ihtimalinin tetkike muhtac olduğunu belirtmemiz gerekir. Şimdilik biz bu tekkenin diğerinden ayrı olduğunu kabul ederek incelemeyi uygun bulduk.

Bu Mevlevihane, XIX. yüzyılın ikinci yarısında Halep Şehri’nin dışarısında ${ }^{54}$ olup "Mevlevî Şeyh Ebubekir el-Vefâî Dergâhı" adıyla anılmaktadır. Yüzyılın sonlarında dergahın tamire ihtiyaç duyması nedeniyle postnişini Mustafa Muzaffer Dede Dâhiliye Nezâreti'ne bir arzuhal göndermiştir. Dâhiliye Nezâreti'nden söz konusu arzuhal gereğinin yapılması için 12 Şubat 1893 tarihli yazı ile Evkâf-1 Hümâyûn Nezâreti'ne havale edilmiştir ${ }^{55}$.

Aynı dönemde dergahın yiyecek masraflarının karşılanmasında da sıkıntı çekilmektedir. Dergâhın şeyhi olan Mustafa Dede bu sıkıntının bertaraf edilebilmesi için devlet merkezinden yardım talebinde bulunmuştur. Yardım talebine dair gönderdiği arzuhal 5 Şubat 1900 tarihinde Sadarete ulaşmış ve emsaline bakılarak kaç kuruşun tahsisi münasip ise tayin edilerek bildirilmesi i Maliye Nezâreti'nden istenmiştir. Tahsisatın gerçekleşmemesi üzerine Mustafa Dede yardım talebini yinelemiştir. Bunun üzerine Sadaretten Maliye Nezâreti’ne 13 Mart 1900 tarihli gönderilen tezkire ile önceki tebligata göre tahsisatın yapılarak maaş miktarının bildirilmesi istenmiştir ${ }^{56}$. Bu teşebbüsten de sonuç alınamamış olmalı ki Mustafa Muzaffer Dede Sadarete 30 Eylül 1903 tarihli yeni bir arzuhal göndermiştir. Arzuhalde, tekkeye etraftan seyahat için gelenler ile dervişler, müritler ve diğer sakinler için mevcut bütün mali gücünü kullanmasına rağmen yeterli gelmediğini ifade etmiştir. Maliye Hazinesi mahlûlâtından ya da tekkenin hazine tarafından toplanan 50000 kuruşu aşan gelir fazlasından 500 kuruş yiyecek ya da maaş tahsis edilmesini istemiştir ${ }^{57}$. Bu arzuhal Sadaret tarafından 3 Ekim 1903 tarihli yazı ile Maliye Nezâreti'ne havale edilerek gereğinin yapılması istenmiştir ${ }^{58}$. Maliye Nezâreti'nden gelen 13 Aralık 1903 tarihli cevâbî yazıda, Ebûbekir Vefâî Vakfı'nın Halep Vilâyeti bütçe defterlerinde yıllık 17708 akçe geliri olduğu kayıtlı olmasına karşıllk henüz mahallerinden istenen defterlerin gelmemesi nedeniyle işlem yapmanın mümkün olmadığı ifade edilmiştir. Diğer taraftan münhalât hesabındaki para miktarı 5000 kuruşa ulaşmadıkça oradan da maaş tahsisine izin verilmemesi ve bu miktarın da henüz mevcut olmaması nedeniyle hazine tarafından maaş tahsisi hususunda bir şey söylenemeyeceği bildirilmiştir ${ }^{59}$. Bu yazı üzerine Mâliye Nezâreti'ne Sadaretten gönderilen 24 Aralık 1903 tarihli yazıda, muhtâcîn maaşlarından 5000 kuruştan fazla para artması halinde dergâhın postnişîni Mustafa Muzaffer Dede’ye münasip miktar maaş tahsis edilmesi talimatı verilmiştir ${ }^{60}$.

Konuyla ilgili diğer bir yazışmadan dergâhın yiyecek masrafları için 250 kuruş tahsis edil-
53 COA. BEO., 927/69508/1.
54 COA. BEO., 1455/109120.
55 COA. DH.MKT., 778/48/1.
56 COA. BEO., 1455/109120.
57 COA. BEO., 2661/199514/3.
58 COA. BEO., 2183/163680.
59 COA. BEO., 2661/199514/2.
60 COA. BEO., 2238/167785. 
diği ancak bu paranın yetersiz görülerek artırılma talebinde bulunulduğu ortaya çıkmaktadır. Bu hususta Sadaretten Maliye Nezâreti'ne bir tezkire gönderilmiş ancak Maliye Nezâreti'nden gelen cevapta isteğin yerine getirilmesinin mümkün olmadığının bildirildiği anlaşılmıştır. Dergâhın yiyeceğinin yetersizliğinin mahalli mazbatasıyla sabit olmasına binaen arz olunan yiyecek parasının şimdilik emsali gibi 500 kuruşa çıkarılması talebi dergâhın şeyhi Mustafa Muzaffer Dede tarafından 14 Aralık 1903 tarihli yeni arzuhalle talep edilmiştir ${ }^{61}$. 4 Eylül 1905 tarihinde Sadarete yeni bir arzuhal daha göndererek, daha önceki taleplerin yerine getirilmemesine dikkat çekilerek yiyecek tahsisatına zam yapılarak adaletin sağlanması talep edilmiştir ${ }^{62}$.

Sadaretten 7 Eylül 1905 tarihinde Mâliye Nezâreti'ne yeni bir yazı daha gönderilerek, dergâh postnişîni Mustafa Muzaffer Dede'nin gelen yeni arzuhali ek olarak gönderilmiş ve arzuhâlin içeriği ve daha önce bildirilen hususlar da dikkate alınarak gereğinin yapılması istenmiştir ${ }^{63}$.

Vakıf köylerin öşürlerinin hazine tarafından zapt edilerek bedele bağlanması ve büyük vakıfların bundan istisna tutulmasına dair padişah iradesi bulunmaktadır. Halep İdare Meclisi, Mevlevi Şeyh Ebubekir el-Vefâî Hazretleri'nin Halep'te bulunan dergâhına bağlı beş köyün öşrünün de müstesna tutulması talebini Sadarete iletmiştir. Sadaret bu hususu Mâliye Nezâreti'ne havale etmiş, Maliye Nezareti de Şurâ-yı Devlet'ten görüş istemiştir. Daha sonra Meclis-i Mahsûs-1 Vükelâ'dan istisnasının uygun olmadığına dair karar çıkmıştır. Ancak mahallince takdir edilmiş olan bedelin verilmesi kararlaştırılmış olduğu halde söz konusu paranın ödenmemesinin sebebinin anlaşılamadığı ifade edilerek, dergâh şeyhinin Halep'ten özellikle bu iş için İstanbul'a gelerek işi takip ettiği ve Bâb-1 Âlî’ye sürekli müracaat ettiği belirtilerek gerekli muamelenin süratle yerine getirilmesi emredilmiştir(11 Kasım 1905) ${ }^{64}$.

Şeyh Mustafa Muzaffer Dede Efendi, vakıf köyleri öşrünün bedel-i tahmîse bağlanması hakkındaki tahkikatın diğer vakıfların tahkikatının tamamlanmasına bağlanmasının dergâhın harab olması sonucunu doğuracağını belirtmiştir. Bu sebeple vakıf hakkındaki tahkikatın diğerlerinden ayrılarak süratle yapılması hususunun Halep Vilâyeti'ne bildirilmesini talep etmiştir. Bunun üzerine Sadaretten Maliye Nezâreti ve Halep Vilâyeti'ne gönderilen yazı ile, vilayet defterdârının başkanlığında oluşturulacak komisyon aracılığıyla söz konusu vakıf hakkındaki tahkikatın tamamlanması, gerekli mazbatanın süratle düzenlenerek söz konusu vilayete bildirilmesi ve bu hususta defterdârlığa da tebligatta bulunulması istenmiştir(6 Ocak 1906) ${ }^{65}$.

Vilâyet defterdarı başkanlığında oluşturulacak komisyon tarafından yapılacak tahkikat uzamıştır. Bu sebeple dergâh postnişini Şeyh Mustafa Muzaffer Dede mağduriyetini dile getirerek gerekli muamelenin bir an önce yapılması talebinde bulunmuştur. Sadaretten Mâliye Nezâreti ile Halep Vilâyeti'ne 7 Mart 1906 tarihli yeni bir yazı daha gönderilmiştir. Vilâyete gönderilen yazıda, daha önce defalarca bildirildiği üzere gerekli tahkikatın bir an önce yapılması ve bir daha tekide gerek bırakılmaksızın istenilen mazbatanın süratle düzenlenerek şeyhin beklemesine mahal bırakılmamak için acilen gönderilmesi istenmiştir. Aynı zamanda, Maliye Nezâreti'nce de defterdarlığa buna göre tebligatta bulunulması emredilmiştir ${ }^{66}$.

Şeyh Abû-Bakr el-Vefâî Zaviyesi, Mevlevilerden alınmış ve Kâdirîhâne yapılmıştır. Bu za-
61 COA. BEO., 2661/199514/4.
62 COA. BEO., 2661/199514/5.
63 COA. BEO., 2661/199514/1.
64 COA. BEO., 2702/202594.
65 COA. BEO., 2735/205090.
66 COA. BEO., 2775/208100. 
viye tamamıyla kapanmıştır. Müştemilatı parça parça Evkaf Dairesi tarafından mesken olarak kiraya verilmektedir ${ }^{67}$.

\section{Hazariye Zâviyesi}

Halep’teki Mevlevi Tekkesi’ne bağlı Bâbü'l-cenân haricinde “Hazariye Zâviyesi” ismiyle ayrı bir zaviye bulunmaktadır. Bu zaviyenin, Evkâf-ı Hümâyûn Hazinesi dahilinde bir de vakfı bulunmaktadır. Bu vakfın, değirmen, bostan ve sair arazisi vardır. Vakfın gelirleri Halep Evkâfi Sandığı tarafından toplanarak tekke vakfına verilmektedir. Vakfın gelir kaynakları, Antakya'da değirmenler, bostan, zaviyenin yanında iki parça yer olup yıllık 5100 akçe geliri bulunmaktadır. Bu gelirden şeyhe günlük 10 akçe verilmekte ve 1500 akçesi zaviyenin bakım ve onarım giderleri ile zaviyeye gelip-gidenlerin yiyecek masrafları için harcanmaktadır. Hazariye Zâviyesi'nin 20 Nisan 1858 tarihinde şeyhi ve vakfının mütevellisi Mevlevî Abdülgani Efendi'dir ${ }^{68}$.

\section{Şam Mevlevihanesi}

Şam Mevlevihanesi, 1585 yılında Şam valisi Hasan Paşa tarafından tesis edilmiştir ${ }^{69}$. Dergâhın ilk şeyhi, Karamanlı Derviş Kartal Muhammed Dede'dir(ö.1624). Kartal Dede'nin hayatını kaybetmesi üzerine Abdurrahman Çelebi postnişin olmuştur. Daha sonra, Sabuhi Ahmed Dede ve Karamânî Derviş Hamza Dede de burada şeyhlik yapmışlardır. Sabuhi Ahmet İstanbul Yenikap1 Mevlevihanesi şeyhliğine gelmeden önce on sekiz yıl Şam'daki tekkeyi yönetmiştir. XIX. yüzyılda Şeyh Mustafa Dede, Şeyh Said Efendi, Said Ahmed el-Mevlevî, Atâullah el-Mevlevî şeyh olarak görev yapmışlardır. Sabrî Dede, otuz seneden fazla Şam Mevlevihanesi şeyhliği yaptıktan sonra vefat etmiş ve yerine oğlu Mehmet Emin Efendi tayin edilmiştir. Mehmet Emin Efendi'nin fukaradan olması nedeniyle kendisine münasip miktarda maaş tahsisi hakkında Suriye Vilâyeti İdare Meclisi'nden 23 Ekim 1898 tarihli mazbata Dâhiliye Nezâreti'ne gönderilmiş ve oradan da 17 Aralık 1898 tarihli yazı ile Sadarete havale edilmiştir. Daha sonraki dönemde Muhammed Said Dede de burada şeyhlik yapmıştır. Muhammed Said Dede $1927^{\prime}$ de vefat etmiştir ${ }^{70}$.

Şam’daki Mevlevihane şehri çevreleyen surların yaklaşık 400 metre kuzeybatısında yer almaktadır ${ }^{71}$. Süleymaniye Tekkesi ve Hicaz Demiryolu gibi Osmanlı eserlerinin yoğunlukta bulunduğu bir mevkidedir ${ }^{72}$.

Mevlevi dervişlerinin zaman zaman seyahat amacıyla Arap coğrafyasına gittikleri ve bunların öncelikle Halep ve Şam’a uğradıkları anlaşılmaktadır. Bunlar bazen gittikleri yerlerdeki idarecilerin kendilerine hürmet gösterip yardımcı olmaları için devlet merkezinden bir tavsiye mektubu mahiyetinde yazı talebinde bulunurlard1. 21 Haziran 1859 tarihli Sadaretten, Şam Valisi Ahmet Paşa'ya gönderilen yazı buna örnek gösterilebilir. Yazıda, Mevlevi tarikatından Derviş Hüseyin Efendi'nin seyahat amacıyla Şam tarafına geldiği belirtilerek kendisine hürmet gösterilmesi ve gerekli yardımın yapılması istenmiştir ${ }^{73}$.

Arap coğrafyasındaki Mevlevihanelerin XIX. yüzyılda gelirleri genellikle masraflarını karşılamaya yetmemektedir. Bu sebeple devlet merkezinden sıklıkla yardım istenmekte ve devlet

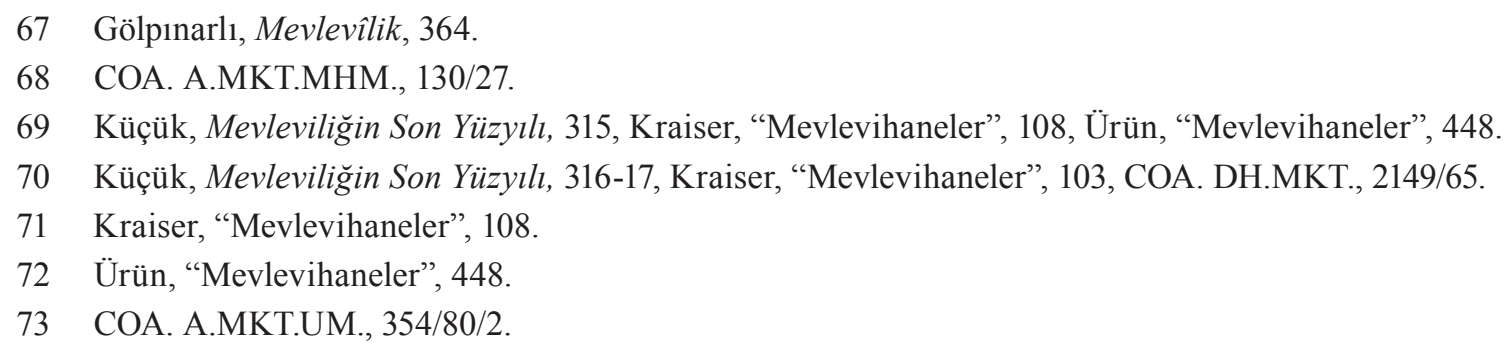


merkezinden bazen şeyhe, bazen Mevlevihaneye, bazen de her ikisine muhtelif kalemlerden para tahsis edilmektedir. Bu paraların verilmesinin aksaması durumunda da ciddi mali sıkıntıya düşülerek Mevlevihanenin hizmetleri yürütülememektedir. Mesele, yine devlet merkezine müracaatla aşılmaya çalışılmaktadır. Şam Mevlevihanesi'nin hem şeyhi hem de Mevlevihane fukarası için Şam Hazisesi'nden tahsisat bulunmaktadır. 1860 yılında bu tahsisatla ilgili bir problem çıkmıştır. Problemi aşmaya yönelik olarak Şam Mevlevihanesi Şeyhi Mehmet Said Efendi Sadaret'e 20 Kasım 1860 tarihli bir mektup göndermiştir. Mektupta belirtildiğine göre, postnişini bulunduğu Mevlevihane'nin Şam hazinesinden tahsis edilmiş olan aylık 750 kuruş ile yıllık beş çuval buğday ile beş çuval arpa verilmektedir. Ancak aylık 750 kuruşun verilmesine devam edildiği halde buğday ile arpanın verilmesinin tehir edildiği hazine tarafından bildirilmiştir. Buğday ve arpa şeyhe ait olmayıp dergâhta hücrelerde oturan tarikat mensupları ile sair seyahat eden misafirlerin yemeleri içindir. Bu sebeple buğday ve arpanın verilmesi tehir edilecek olur ise dergâhın bütün vakıf gelirinin aylık 45 kuruştan ibaret olduğu dikkate alındığında idarenin tamamıyla imkânsız hale geleceği ve dervişlerin perişan olacağ ifade edilmiştir. Nihayetinde kendisinden önceki şeyhler döneminde ve kendisinin göreve gelmesinden itibaren 18 senedir almakta olduğu maaş, arpa ve buğdayın eskisi gibi verilmeye devam edilmesi ve dergâhın ayakta kalmasının sağlanması talep edilmiştir ${ }^{74}$. Sadaretten, 23 Kasım 1860 tarihli Şam Valisi Emin Paşa’ya gönderilen yazıda, söz konusu dergahın bahsedildiği şekilde arpa ve buğday tayinatının olup-olmadığı ve var ise ne sebeple kesildiğinin belirlenmesi için gerekli tahkikatın yapılarak sonucun bildirilmesi istenmiştir ${ }^{75}$. Bu tahkikat sonrasında meselenin nasıl sonuçlandığına ilişsin bilgiye ulaşamadık ancak yaklaşık bir yıl sonra Mevlevihanenin postnişini Şeyh Mehmet Said Efendi, Mevlevi dergahına yıllık olarak tahsisli bulunan arpa ve buğdayın eskiden olduğu gibi verilmeye devam edilmesi hususunda 18 Ağustos 1861 tarihli yeni bir mektup göndermiştir. Söz konusu mektup Sadaretten Evkâf-1 Hümâyûn Nezâreti'ne havale edilerek gereğinin yapılması istenmiştir ${ }^{76}$. Bu mektup meselenin çözülemediği ve daha sonra da çözümlenmesi çabalarının devam ettiğini göstermektedir.

XIX. yüzyılın sonlarında Mevlevihane bakım ve onarıma ihtiyaç duymaktadır. Ancak bakım ve onarım masraflarını karşılayacak vakfi veya herhangi bir geliri bulunmamaktadır. Dergâhın postnişini, Mevlevihane'nin padişah tarafından Allah rızası için yaptırılmasını talep etmiştir. Belediye tarafından yapılan keşif sonucunda, dergâhın muntazam bir şekilde aslına uygun bir şekilde tamiratının yapılmasının çok masraf gerektirdiği, en zaruri yerlerinin tamiratının yapılması için bile 20.000 kuruşa ihtiyaç olduğu anlaşılmıştır. Suriye Vilâyeti İdare Meclisi'nden Dâhiliye Nezâreti'ne gönderilen 30 Mayıs 1310 tarihli yazıda, dergâhın herhangi bir gelirinin bulunmaması nedeniyle tamiratının mahallince yapılmasının mümkün olmadığı dile getirilmiştir. Aynı zamanda dergâhın terk edilmesinin de bilâhare tamamıla harap olması sonucunu doğuracağı ifade edilmiştir. Söz konusu paranın diğer vakıfların fazla gelirlerinden karşılanması, şayet mümkün olmaz ise postnişinin talebi gereğince Hazîne-i Hâssa'dan karşılanmasına ilişkin mazbata Dahiliye Nezâreti'nden 10 Temmuz 1894 tarihli yazı ile Sadarete takdim edilmiştir ${ }^{77}$. Sadaret'ten bu husus 17 Temmuz 1894 tarihli yazı ile Evkâf-1 Hümâyûn Nezâreti’ne bildirilmiştir ${ }^{78}$. Evkâf-1 Hümâyûn Nezâreti'nden Sadarete gönderilen 25 Eylül 1894 tarihli cevabi yazıda, söz konusu dergâhın vakfinın bulunmadığı, tamirat için Evkâf Hazinesi bütçesinde tahsisatın olmadığı ve vakıf gelirlerinden

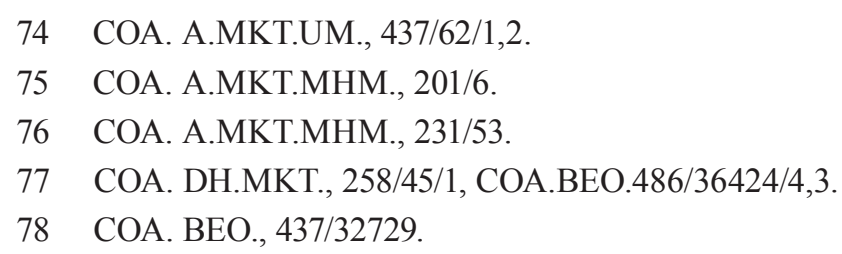


vakıf şartları haricine para sarf edilmesinin mümkün olmadığı ifade edilmiştir ${ }^{79}$. Sadaret de bu hususu 1 Ekim 1894 tarihli yazı ile Dâhiliye Nezâreti'ne ${ }^{80}$, Dâhiliye Nezâreti de 13 Ekim 1894 tarihli yazı ile Sûriye Vilâyeti'ne bildirmiştir ${ }^{81}$.

\section{Kahire (Mısır) Mevlevihanesi}

Dîvânî Mehmet Çelebi bazı dervişleriyle birlikte Mısır'a giderek burada Mevleviliğin tanıtımını yapmış, hapiste bulunan İbrahim-i Gülşenî’nin tahliye edilmesini temin etmiştir. Kahire'de bir süre kalan Çelebi, Sâfî̀ Ahmet Dede’yi postnişîn olarak bırakıp, Mısır'dan ayrılmıştır. Dîvânî Mehmet Çelebi'nin bu faaliyetlerinin, Mısır'ın Yavuz Sultan Selim tarafından fethinden birkaç yıl önce gerçekleştirildiği ifade edilmektedir. O tarihlerden itibaren Mevlevilik, Mısır'da da yayılmaya başlamıştır ${ }^{82}$. Mısır'da Mevlânâ düşüncesi Suudi Arabistan ve Körfez ülkelerinden farklı olarak büyük bir ilgi görmüştür ${ }^{83}$.

Kâhire Mevlevihanesi, Suku Salibe yakınlarındaydı. Birçok derviş hücreleri ve semâhânesi ile büyük bir tekkeydi ${ }^{84}$. Mevlevihane, Tolonoğlu Camii ile Sultan Hasan Camii arasında uzanan, er-Rukbiyye Caddesi civarındaki es-Suyûfiyye Caddesi'ndedir. Sungur Sadi Medresesi avlusunda inşa edilmiştir ${ }^{85}$.

Mevcut semâhânenin, XIX. yüzyılın ilk yarısında yapıldığı ve Said Paşa'nın inşa ve tamirleriyle bugünkü halini aldığı ifade edilmektedir. Semâhânenin kubbe göbeğinin kitâbesi 1857, sütunların üzerindeki ise 1865 tarihlidir. Mevlevihane, Osmanlı idare merkezinin yer aldığı Kahire Kalesi'nin ayağında daha çok Türkler' in oturduğu tarihî Hilmiye semtinde Şâriussüyûfiye'nin başlangıcında bulunmaktadır ${ }^{86}$.

Çeşitli sebeplerle birçok Mevlevi dedesi Kahire Mevlevihanesine uğramıştır. IV. Mehmed'in tahttan indirilmesi olayına adı karışan Konyalı Nesîb Yusuf Dede bunlardan biridir. Nesîb Dede bilahare Ankara, Şam ve Kahire Mevlevihaneleri şeyhliklerinde de bulunmuştur ${ }^{87}$.

4 Eylül 1801 tarihli Dahiliye Nezâreti'nden Konya'da bulunan Çelebi Efendi'ye gönderilen yazıya göre, Mısır Mevlevihanesi şeyhliği daha önce Çelebi Efendi tarafından Şeyh Hacı Mehmet Efendi'ye tevdi edilmiştir. Bu hususta gerekli olan meşihatname de kendisine verilmiştir. Mehmet Efendi Mısır'a tekkeye ulaştığında kendisinden önceki şeyh olan Salih Efendi ile hesap görmek istediğinde, Salih Efendi hesap görmeye yanaşmamış, meşihati bırakmak istemeyerek firar etmiştir. Mehmet Efendi ise iyi halli, dünyaya rağbet etmeyen, inayete layık olması yanı sıra meşihat senedi kendisine verilmiş olmasına dayanarak posta oturmasından itibaren kendi malı ile tekkenin tamiratına başlamıştır. Bu sebeple söz konusu Salih Efendi'nin şeyhliği tasarruf etme talebine müsaade olunmayarak Mehmet Efendi'nin tekke şeyhliğinde bırakılmasına dair şeyhlik mektubunun

\footnotetext{
79 COA.BEO., 486/36424/2

80 COA. DH.MKT., 258/45/2, COA.BEO., 486/36424/1.

81 COA. DH.MKT., 258/45/3.

82 Hasan Özönder, "Mevleviliğin Mısır'daki Temsilciliği: Kahire Mevlevî-hânesi”, II. Milletlerarası Mevlânâ Kongresi (3-5 Mayıs 1990) içerisinde, (Konya: Selçuk Üniversitesi, 1991), 178.

83 Ürün, "Mevlevihaneler", 451.

84 Küçükkaya, "Mevlevihane ve Tekkeler", 185.

85 Özönder, "Kahire Mevlevî-hânesi”, 178-179.

86 Barihüda Tanrıkorur, "Mısır Mevlevîhânesi", DIA 29 içerisinde, (Ankara: Türkiye Diyanet Vakfı, 2004), 586.

87 Kraiser, "Mevlevihaneler", 103, 111.
} 
kendisine gönderilmesi istenmiştir ${ }^{88}$.

Mevlevi şeyhleri Arap coğrafyasına seyahatleri öncesinde, ilgililerin kendilerine yardımcı olmalarını sağlamak üzere devlet merkezinden tavsiye mektubu talep ederlerdi. Bunlara devlet merkezinden olumlu yaklaşılarak bu yönde mektuplar yazdıklarına ilişkin örnekler bulunmaktadır. Mesela, Ağustos 1852'de Mevlevi şeyhlerinden İbrahim Efendi seyahat maksadiyla Mısır tarafina gidecek olmuş ve bir tavsiyename yazılması talebinde bulunmuştur. Söz konusu kişinin zamanın Hâfız Osmanı gibi hüsn-i hattı bulunduğundan lutfa şayan görünmüş ve Mısır Valisine bir tavsiyename gönderilmesi kararı alınarak gereğinin yapılması görevi Serasker Paşa'ya verilmiştir (8 Ağustos 1852) ${ }^{89}$. Yine Sadaret Mektûbî Kalemi’nden Misır Valisine gönderilen 12 Ağustos 1852 tarihli yazıda, Mevlevi tarikatı şeyhlerinden Mesnevîhân Şeyh İbrahim Efendi'nin o tarafa gittiği ifade edilerek kendisinin hürmete layık bir kişi olması hasebiyle işlerinde yardımcı olunması ve aynı zamanda gerekli hürmetin gösterilmesi istenmiştir ${ }^{90}$. Bu İbrahim Efendi Mısır Mevlevihanesi şeyhliği yapan İbrahim Rüşdü Efendi olmalıdır. Mısır Mevlevihanesi Şeyhi İbrahim Rüşdü Efendi, Mısır'da yeniden evlenmiştir. 1856'da diğer eşi Hatice Hanım'1 İstanbul'a göndermek üzere iken Hatice Hanım kendisine bir miktar maaş tahsis etmesini yahut boşamasını teklif etmiştir. Ancak maaş tayin etmediği gibi aynı zamanda boşamadan eli boş olarak İstanbul'a göndermiştir. İbrahim Rüştü Efendi'nin Mısır'da hatırlı bir kişi olması nedeniyle de Hatice Hanım'ın hakkını araması mümkün olmamıştır. İstanbul'dan defalarca zaruretini kendisine bildirmesine rağmen bir cevap alamamıştır. Hatice Hanım'ın herhangi bir geliri ve geçim kaynağı olmaması nedeniyle üç sene içerisinde hayli eşyasını satmış ve bazı eşyalarını ise rehin vererek beş bin kuruştan fazla borç yapmıştır. Hatice Hanım durumunu bir yazı ile Sadaret'e arz etmiştir. Aynı zamanda Şeyhin Mısır'da mahkemeye çağrılarak borçları için gerekli paranın ondan alıverilmesini ve her ay zaruri ihtiyaçları için de ikişer yüz kuruşun gönderilmesi için Misır Valisine bir emirname gönderilmesini talep etmiştir $^{91}$. 21 Eylül 1859 tarihli Sadaret’ten Mısır Valisi'ne gönderilen yazıda konu özetlenerek meselenin çözümü için gerekli kişilere ihale edilmesi istenmiştir ${ }^{92}$.

Hüseyin Azmî Dede de, 1865 'te kardeşi Hüsameddin Dede ile yaşadığ nucu Gelibolu'dan ayrılıp Mısır'a gitmiş ve 1870 yılında Kahire Mevlevîhanesi şeyhliğine atanması ile uzun yıllar Kahire'de kalmıştır. Azmi Dede, Kahire Mevlevihanesi'nde 24 sene şeyhlik yapmıştır. Onun döneminde Mevlevihane bir zaviye iken âsitâneye dönüşmüştür. Hüseyin Azmi Dede'nin ortanca oğlu Mehmed Bahâeddin Dede, babasından sonra şeyhliği üstlenmiştir. Mehmed Bahaeddin'den sonra oğlu Mustafa Dede Efendi ve ondan sonra da muhtemelen Mustafa Dede'nin oğlu Musa Bahaeddin şeyh olmuştur ${ }^{93}$.

1925'ten sonra Türkiye'de tekkelerin kapatılması üzerine Misır Mevlevihanesi, Halep Mevlevihanesi'nde yeni kurulan çelebi makamından yönetilmiştir. 1946'da Mevlevihane huzurevi ve fakirler için bir dispanser haline getirilmiştir. Bu dönemde yaşlilarla birlikte birkaç derviş de burada kalmıştır. 1954'te Evkaf Bakanlığı Mısır'daki diğer tekkeler gibi Mevlevihaneye de el koyunca dervişler buradan ayrılmıştır. Bakımsız kalan Mevlevihanede 1984'ten itibaren geniş çaplı bir onarım gerçekleştirilmiştir. Bugün Mevlevihane Mısırlı öğrenciler için bir restorasyon ve

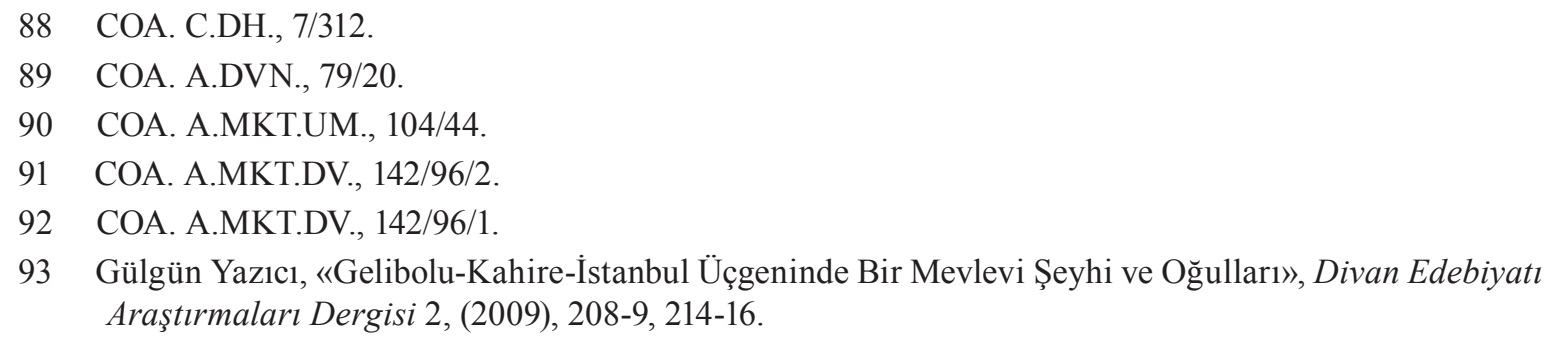


arkeoloji okulu olarak kullanılmaktadır ${ }^{94}$.

\section{Mekke Mevlevihanesi}

Mevlevihane ile ilgili ulaşabildiğimiz en eski tarihli belge 29 Aralık 1697 tarihlidir. Bu belgeye göre Mekke'de bulunan Mevlevi tekkesinin yiyecek masrafları için tahsisli Şam havalisi malından günlük elli akçe tahsisat bulunmaktadır. Aynı zamanda tekke mescidi imamının maaşı için de on akçe ödenmektedir. Görevli olan kişinin beratı kaybolmuş ve yeni berat talebinde bulunulmuştur. Defterhaneden çıkarılan derkenardan şeyhin Hüseyin Dede isminde biri olduğu anlaşılmaktadır. Söz konusu kayda göre yeni berat verilmesine dair 30 Aralık 1697 tarihli buyruldu sadır olmuştur. Bu kayıtlar Mekke Mevlevihanesinin bu tarihten öncesinde tesis edildiğinin açık bir göstergesidir. Bir başka belgenin derkenar kaydından Mevlevihane hakkında ilave bilgiler edinmek mümkün olmaktadır. Bu belgede Mekke-i Mükerreme Emiri Şerif Yahya'nın devlet merkezine gönderdiği bir yazıda verdiği bilgilere dayandırılarak Mekke Mevlevihanesi, Şerif Mesud'un Divan Katibi La 'lî Mehmet Efendi tarafından yaptırılmıştır. Mevlevihanenin "vazife-i mu'ayyenesi” vakıf şartnamesi gereğince oğulları ve kızları tarafından tasarruf edilegelmiştir. Ancak Mevlevihane şeyhi Mehmed Efendi'den sonra şeyhlik makamı boş kalmıştır. H.1235 (M.1819-1820) yılında Mekke-i Mükerreme Mollası Mehmet Sadullah Efendi ile Mekke eşrâfı arzuhal göndererek, Mevlevihane şeyhliğinin uzun zamandır boş olduğu ve haraba yüz tuttuğunu bildirmişlerdir. Aynı zamanda Konyalı Ali Efendi'nin söz konusu meşihata layık olduğunu ve kendisinin tekkeyi tamiri ile bakım ve onarımını yapacağını bildirerek kendisinin şeyh olarak tayin edilmesini istemişlerdir. Bunun üzerine Mehmet Efendi'den boşalan şeyhlik makamına sülaleden olmayan mücâvirînden Konyalı Ali Efendi tayin olunmuştur. Ali Efendi'nin vefatından sonra vâkıfın ailesinden kişiler hakkın kendilerine ait olduğu iddiasıyla ortaya çıkmışlardır. Bu arada Şam 'dânî İbrâhim şeyhliğin kendisine verildiğini iddia etmiştir. Kayıtlar incelendiğinde görevin İbrahim'e verildiğine dair bir bilginin olmadığı anlaşılmıştır. Aslında Ali Efendi tayin edilir iken şeyhliğin vâkıfın evlâdına tahsisli olduğunun farkına varılmadan görevlendirme yapılmıştır. Şam‘dânî İbrâhimıin tayin hususu da benzer şekilde gündeme gelmiştir. Nihayetinde, Devlet merkezinden Konya dergâhına gönderilen 17 Kasım 1824 tarihli yazı ile evlâda şart koşulan görevlere müdahalenin uygun olmadığı ifade edilmiştir. Aynı zamanda bu türden şeyhlik görevlendirilmelerinin Çelebi Efendi'nin görüşüne göre yapıldığı ifade edilerek, şerifin verdiği bilgiler dikkate alınarak münasip olanın kendisine bildirilmesi emredilmiştir ${ }^{95}$.

Mekke'de bazı hizmetlerin Mevlevilere verildiği anlaşılmaktadır. Mesela, sebilcilik hizmeti Mevlevi tarikatından Abdullah Dede Efendi'ye verilmiştir (2 Ekim 1860) ${ }^{96}$. Mekke'de Mevleviler tarafından tesis edilen vakıf eserleri de bulunmaktadır. Bunlara bir örnek olarak Mehmed Hüseyin el-Hindî’nin oğlu Abdülhâlık el- Mevlevi tarafından yaptırılan Medrese'yi gösterebiliriz ${ }^{97}$.

\footnotetext{
94 Tanrıkorur, "Misır Mevlevîhânesi”, 587.

95 COA. İE.EV., 26/3092, COA. HAT., 550/27133-D, Ayrıca bkz. Mustafa Güler, "XVIII. Yüzyılın Sonunda Mukaddes Şehirlerde Yaşayan Mevleviler, Sultan Dîvânî ve Mevlevîlik I içerisinde, ed. Mustafa Karazeybek (Afyonkarahisar: Afyon Kocatepe Üniversitesi Eğitim Sağlık ve Bilimsel Araştırma Vakfi, 2015), 76.

96 COA. A.MKT.MHM., 196/67.

97 COA. BEO., 3879/290921.
} 


\section{Medine-i Münevvere Mevlevihanesi}

Medine'deki ilk Mevlevihane XVI. Asırda Sultan III. Murad (1571-1595) zamanında yapt1rılmıştır ${ }^{98}$. Medine Mevlevihanesi ile ilgili olarak ulaşabildiğimiz arşiv vesikaları genel itibariyle XIX. yüzyıla aittir. 1843 tarihli bir belgeye göre, Medine-i Münevvere Mevlevihanesi şeyhliğine Seyyid Mehmet Nuri Dede tayin olunmuş, gitmek üzere iken kaza geçirmiş, elinde olan harçlığını doktor ve sair zaruri masraflar için harcamıştır. Bu sebeple görev yerine gidememiştir. Devlet merkezine bir arzuhal göndererek, iki çocuğu ve bir derviş ile birlikte dört kişinin Medine'ye gitmesine yetecek bir miktar harçlik verilmesini talep etmiştir ${ }^{99} .7$ Ağustos 1843 tarihli İrade ile Seyyid Mehmet Nuri Dede’ye Maliye Hazinesi’nden 1000 kuruş verilmesi kabul edilmiştir ${ }^{100}$.

21 Ekim 1852 tarihli diğer bir belgeden, bir yıl önce Medine-i Münevvere tarafina giden Mevlevi Tarikatı'ndan Mustafa Reşid Efendi'ye hürmet gösterilmesi ve yardımcı olunması hususunda Harem Şeyhi'ne bir yazı yazılmasına rağmen herhangi bir sonuç alınamadığı anlaşılmaktadır. Bunun üzerine sıkıntıya düşen Mustafa Reşid Efendi devlet merkezine müracaat ederek kendisine münasip bir miktar maaş bağlanmasını talep etmiştir. Konu Meclis-i Vâlâ'ya havale edilmiş ve daha önce gönderilen yazıyı tekiden Harem Şeyhi'ne yeni bir yazı daha gönderilmiştir ${ }^{101}$. Harem Şeyhi'ne hitaben yazının gönderildiği Mustafa Reşit Efendi’ye de bir yazı ile bildirilmiştir ${ }^{102}$. Ancak belgede Mustafa Reşid Efendi'nin Mevlevihane’nin şeyhi olup-olmadığına ilişkin bilgi mevcut değildir.

Medine, hacca giden bütün Müslümanların ziyaret ettiği bir yer olmasının yanı sıra Mevlevi dervişlerinin de sıklıkla uğradığı bir yerdir. Bu sebeple zaman zaman Mevlevihanenin masraflarının karşılanmasında güçlük yaşanmıştır. Bu sebeple devlet merkezinden yardım talep edilmektedir. Örneğin 1854 senesinde dönemin Medine Mevlevi şeyhi El-Hac Mustafa Aşkî Dede mevcut tayinatın yetersizliğini ifade ederek ek tayinat istemiştir. Bunun üzerine pirinç, et ve yağ ilavesi yapılmıştır ${ }^{103}$.

Medine-i Münevvere İmam Ali Mescid-i Şerifi imamı ve Mevlevi Zaviyesi postnişini 1899 tarihinde Ali Molla Dede Efendi'dir. Şeyhin maaşı ve tahsisatı olmaması nedeniyle, yirmi kişilik ailesi ve hac zamanında zaviyesine misafir olan fukara ve dervişlerin iaşe ve yedirilmesi hususunda zorluk ve darlık çekilmektedir. Ali Molla Dede Efendi dergâha benzerleri gibi yiyecek tahsis edilmesine dair bir arzuhali Konya'ya göndermiş ve bu arzuhal Konya Vilayeti'nden 17 Aralık 1899 tarihli bir yazı ile Sadarete gönderilmiştir. Sadaret de söz konusu yazılar ile hazineden tahsisli olup boş olan bazı maaşları gösteren bir listeyi 10 Ağustos 1900 tarihli bir üst yazı ile Mâliye Nezâreti'ne havale ederek Maliye Hazinesi'nden söz konusu dergâha münasip miktar yiyecek parası tahsis edilmesi için gereğinin yapılmasını istemiştir ${ }^{104}$. Daha sonra Sadaret'ten Mâliye Nezâreti'ne gönderilen Kasım 1900 tarihli diğer bir yazıdan anlaşıldığına göre, 27 Eylül 1900 tarihli tezkire ve 1 Kasım 1900 tarihli İrâde-i seniyye ile boş olan bazı maaşlardan söz konusu zaviyeye 500 kuruş yiyecek parası tahsis edildiği belirtilerek gereğinin yapılması emredilmiştir ${ }^{105}$.

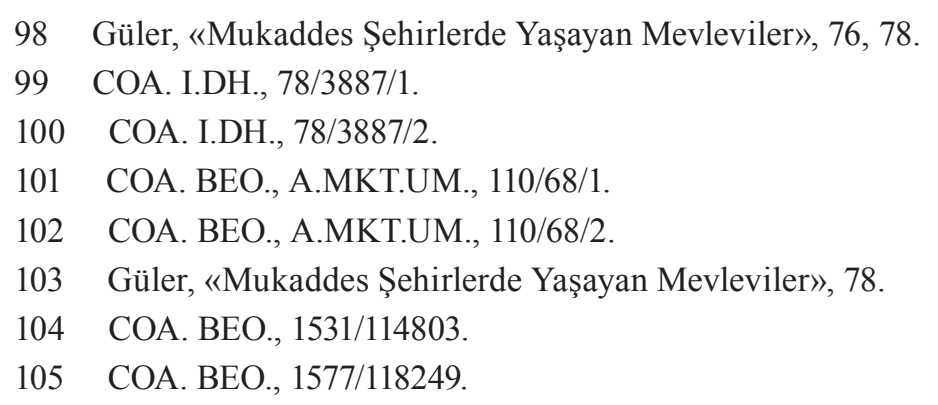




\section{Kudüs Mevlevihanesi}

Mevlevi tarikatı Kudüs'e Memlüklüler döneminde girmiş ve Yavuz Sultan Selim'den itibaren de Osmanlı Kudüsü'nde kökleşen bir müessese olmuştur ${ }^{106}$. Ancak Kudüs Mevlevihanesi H.995 (M.1586/7)'de yapılmıştır ${ }^{107}$. Bu hangâh XVI. yüzyılda Kudüs Livası Kumandanı Hüdâvendigar Bey tarafından yaptırılmıştır. Bina Kudüs'te Sa'diyye Mahallesi’nde bulunmaktadır ${ }^{108}$. Evliya Çelebi, Kudüs'te Bâb-1 Amud'un iç kısmında olduğunu ifade eder. Kudüs'te yetmiş tarikata mensub tekkelerin varlığından bahsederken, en mamur ve bakımlısının Mevlevî Tekkesi olduğunu söyler ${ }^{109}$. Tespit edilebildiği kadarıyla tekkede görev yapan şeyhler, Seyyid Hacı Ali Dede, Şemseddin Dede, Osman Nureddin Dede, Muhammed Arif Dede ve Hilmi Efendi' dir ${ }^{110}$.

\section{Trablusşam Mevlevihanesi}

Mevlevihane, Osmanlı Devleti'nin Arap eyaletleri içinde kurulmuş ikinci en büyük Mevlevihane $^{111}$ olup 1620 yılında Sıssımcı Ali tarafından yaptırılmıştır ${ }^{112}$. Evliya Çelebi, Trablusşam'daki Mevlevihaneyi ziyaret etmiştir. Mevlevihanenin konumunu, kalenin doğu tarafinda, şehrin içinden akan suyun kenarında ve yüksekçe bir yerde olduğunu belirtmektedir ${ }^{113}$. Mevlevihane, Trablusşam'ın ortasından geçen Gumeyza isimli akarsuyun kenarında yüksek bir yerde inşa edilmiştir ${ }^{114}$. Mevlevihanenin hemen yanı başında Mevleviye Değirmeni bulunmaktadır. 20. yüzyılın başında Mevlevihanenin bulunduğu bölgede yeni binaların yapılmaya başlamasıyla dergah güzel konumunu kaybetmeye başlamıştır. 1963'te son Mevlevi şeyhi Enver Mevlevi'nin ölümüne kadar Mevlevihane hizmet vermeye devam etmiştir. Lübnan iç savaşları sırasında büyük zarar görmüştür. Bomba ve füzelerin etkisiyle sema salonunun kubbesi düşmüş, camisi yıkılmış, çeşitli oda duvarları yıpranmıştır. Binanın içinde bulunan tarihi kitabe çalınmıştır. Mevlevihane genel olarak üç ayrı bölüme ayrılabilir. Mevlevihanenin ana işlev birimlerini içeren Semahane ve mescid, misafirhane ve şeyh evinin "Haremlik" adıyla bilinen bölümü ${ }^{115}$.

\section{Kerkük Mevlevihanesi}

Kerkük Mevlevihanesi, Kerkük Kasabası'nın Balak Mahallesinde bulunmaktadır ${ }^{116}$. Kerkük'te bulunan Mevlevi tekkesinin herhangi bir tahsisatı bulunmadığından dergâhta bulunan dervişlerin yiyecek masraflarının karşılanması için vefat eden dört kişinin toplam 230 kuruş on üç para münhal maaşlarının dergâhın postnişini olan Mehmet Hamdi Dede Efendi'ye tahsis edilmesi Bağdat Vilayeti İdare Meclisi'nden gönderilen mazbatada bildirilmiştir. Bu hususta yapılan tahkikatta, İmâm-1 A'zam Hazretleri'nin vakıf fazlası, Cedîd Hasan Paşa Vakfı'ndan ve Hazine tarafın-

106 Hasan Hüseyin Güneş ve Mehtap Kuş, "Kudüs Mevlevihanesi ve Vakfiyeleri üzerine Metodik Bir İrdeleme”, 2. Uluslar arası Sultan Dîvânî ve Mevlevîlik Sempozyumu 1-2 Haziran 2012 Bildiriler içerisinde, ed. Mustafa Oner Uzun (Afyonkarahisar: Afyon Kocatepe Üniversitesi, 2013), 120.

107 Kraiser, "Mevlevihaneler", 109.

108 Güneş ve Kuş, «Kudüs Mevlevihanesi”, 120.

109 Küçükkaya, "Mevlevihane ve Tekkeler", 185.

110 Küçük, Mevleviliğin Son Yüzyılı, 322.

111 Khaled Tadmori, “Trablusşam Mevlevihanesi’nin Mimarisi ve Restorasyon Projesi”, Uluslar arası Mevlânâ Sempozyumu 8-12 Mayıs 2007 İstanbul-Konya Bildirileri 2 içerisinde, ed. Mahmut Erol Kilıç, Celil Güngör, Mustafa Çiçekler (İstanbul: Motto Project, 2010), 851.

112 Küçük, Mevleviliğin Son Yüzyılı, 319.

113 Kraiser, "Mevlevihaneler", 107.

114 Küçükkaya, "Mevlevihane ve Tekkeler”, 184.

115 Tadmori, “Trablusşam Mevlevihanesi”, 851-2, 854.

116 COA. İ.DH., 1268/99658. 
dan mazbut Mesûdî Kiriş Vakfi'ndan dört kişiye toplam 231 kuruş maaş ödendiği tespit edilmiştir. Söz konusu 231 kuruş maaşın 31 kuruşunun hazineye bırakılarak diğer 200 kuruşun dergâhtaki fukara ve dervişlerin yiyecek masraflarının karşılanması için şeyhe tahsis edilmesi Evkâf-1 Hümâyûn Nezâreti'nden Başvekâlet'e sunulan 3 Mart 1880 tarihli yazı ile beyan edilmiştir ${ }^{117}$.

Başvekâlet'ten Evkâf-1 Hümâyûn Nezâreti'ne gönderilen 4 Mayıs 1880 tarihli yazıda bu türden boşta kalan maaşların, «Maaşât Kararnâmesi” gereği hazineye alınması gerektiği ifade edilerek gereğinin yapılması istenmiştir. Ancak Evkâf-1 Hümâyûn Nezâreti’nden Başvekâlet'e sunulan 12 Haziran 1880 tarihli yeni bir yazıda söz konusu hususta "Maaşât Kararnâmesi”"ne dayandırılarak maaşların hazineye alınmasının usul ve hakkaniyete uygun görülemediği ifade edilerek konunun bir kere daha değerlendirilmesi talep edilmiştir ${ }^{118}$. Konu 15 Haziran 1880 tarihinde görüşülmek üzere Şûrâ-yı Devlet'e havale olunmuştur. Şûrâ-yı Devlet'te konu görüşülerek söz konusu maaşların ödendiği yerlerin Maliye Hazinesi ve Maaşât Kanunu ile bir alakasının olmadığı ifade edilerek Evkâf-1 Hümâyûn Nezâreti'nin isteği doğrultusunda gereğinin yapılması kararı verilerek konunun söz konusu nezarete havale edilmesi istenmiştir ${ }^{119}$. Böylece dergâhın yiyecek masraflarının karş1lanmasında kullanılmak üzere aylık 200 kuruşun Postnişîn Mehmet Hamdi Dede Efendi’ye tahsisi gerçekleşmiştir.

Kerkük Mevlevi Şeyhi Hamdi Efendi’ye 2 Temmuz 1886 tarihinde 5. Rütbeden Mecidi Nişanı verilmiştir ${ }^{120}$.

10 Mart 1892 tarihinde Mevlevihanenin postnişini Mevlevi Haydar Efendi’dir. Söz konusu tarihte dergâha aynı yıl Teşrîn-i Sânî sonuna kadar Maliye Hazinesinden Muhtâcîn Maaşlarından aylık 250 kuruş tahsis edilmiştiri' ${ }^{121}$. Haydar Dede'nin Kerkük'te bulunan Mevlevihanesi'ne tahsis edilmiş olan aylık 250 kuruş yiyecek parasının yetersiz gelmesi nedeniyle mahallinden artırılması talep edilmiştir. Bunun üzerine Mevlevihanedeki dervişlerin çok olması dikkate alınarak muhtâcîn maaşları hesabında boş olan 250 kuruşun ilave edilmesiyle tahsis edilen yiyecek parasının 500 kuruşa çıkarılması 11 Eylül 1895 tarihli irade ile gerçekleşmiştir ${ }^{122}$.

Kerkük Mevlevihanesi fukara ve dervişleri yiyeceği olmak ve her kim şeyh olur ise ona verilmek şartıyla Şeyh Mehmet Hamdi Dede Efendi'nin Kerkük Sancağı dergâh yiyecek masrafı olarak aylık 450 kuruş yiyecek ve yıllık 4199 kıyye buğday tayinatı bulunmaktadır ${ }^{123}$.

28 Nisan 1900 tarihli, Kafkasya Kâdi'l-kuzâtı ve Hulefâ-yı Nakşiyyeden Şeyh Osman Nuri Efendi'nin oğlu olup Medîne-i Münevvere ve Ravza-i Mutahhara süpürgecisi Tokatlı Zekeriya isimli birinin dilekçesinden Mevlevi Şeyhi Hamdi Dede'nin çocuksuz olarak bu tarihten önce vefat ettiği anlaşılmaktadır. Zekeriya Efendi vefat eden Hamdi Dede'nin maaşından kendisine münasip bir miktar maaş tahsisi talebinde bulunmuş ${ }^{124}$, ancak söz konusu maaşın Kerkük Mevlevihanesi fukara ve dervişleri yiyeceği olmak ve her kim şeyh olur ise ona verilmek şartıyla Şeyh Mehmet Hamdi Dede Efendi tarafından tasarruf edildiği ifade edilerek reddedilmiştir ${ }^{125}$.

$\begin{array}{ll}117 & \text { COA. SD., 100/45/1. } \\ 118 & \text { COA. SD., 100/45/7. } \\ 119 & \text { COA. SD., 100/45/11. } \\ 120 & \text { COA. İ.DH., 1011/79849. } \\ 121 & \text { COA. İ.DH., 1268/99658. } \\ 122 & \text { COA. İ.ML., 15/40. } \\ 123 & \text { COA. BEO., 1480/110958/3. } \\ 124 & \text { COA. BEO., 1480/110958/4. } \\ 125 & \text { COA. BEO., 1480/110958/3. }\end{array}$


Kerkük Mevlevihanesi Postnişini Hamdi Dede, egzama cilt hastalığına yakalanmıştır. Yaz aylarında hastalığın şiddetinin artması nedeniyle 24 Haziran 1894 tarihli Kerkük Belediye tabibinden aldığg1 Musulda'ki Hammâmü'l-alîl'de altmış gün hamama girmesine dair raporu 27 Haziran 1894 tarihli dilekçe ile Musul Valiliği’ne müracaat ederek söz konusu hamama gitmesine müsaade edilmesini talep etmiştir ${ }^{126}$.

Musul Valisinin Dâhiliye Nezâreti'ne bu hususta nasıl hareket edilmesi gerektiğini sormasına ilişkin gönderdiği yazı, Hamdi Dede hakkında değişik bilgiler içermektedir. Valinin belirttiğine göre Hamdi Dede, Kerkük ahalisinden ve Mevlevi şeyhlerindendir. Gayet zararlı ve fesat çıkaran birisi olması nedeniyle ferman ile İstanbul'a dönememek üzere memleketi olan Kerkük'e gönderilmiştir. Aynı zamanda, 19 Mayıs 1891 tarihli Zaptiye Nezâreti'nden gönderilen bir yazı ile memleketinde oturarak sürekli olarak kendisi hükümetçe de gözetim altında tutulduğu ifade edilerek kesinlikle İstanbul'a dönüşüne veya bir tarafa savuşmasına müsaade edilmemesi bildirilmiştir. Buna karşılık Hamdi Dede, hastalığına istinaden doktor raporu ile birlikte bir dilekçe ile Musul merkezine üç saat mesafede bulunan Hammâmü'l-alîl Kaplıcası'na gitmesine izin verilmesini istemiştir. Musul Valisi durumu özetleyerek nasıl hareket edilmesi gerektiğini 10 Temmuz 1894 tarihli yazı ile Dâhiliye Nezâreti'ne sormuştur ${ }^{127}$. Dâhiliye Mektûbî Kalemi'nden yapılması gereken işlem 8 Ağustos 1894 tarihli yazı ile Zaptiye Nezâreti'nden sorulmuştur ${ }^{128}$. Zaptiye Nezâreti cevâben gönderdiği 14 Ağustos 1894 tarihli yazıda Hamdi Dede'nin gidip-gelişinde refakatinde kabiliyetli bir memur bulundurularak, firarına meydan verilmemek üzere gitmesine izin verilmesinde sakınca olmadığını bildirmiştir ${ }^{129}$. Nihayeti'nde Dâhiliye Mektûbî Kalemi’nden bu defa Musul Vilayeti’ne bu minvalde 22 Ağustos 1894 tarihli bir yazı gönderilmiştir ${ }^{130}$.

Dâhiliye Mektubi Kalemi'nden Sadaret'e gönderilen 16 Nisan 1895 tarihli yazıya göre, Mevlevi Tarikatı şeyhlerinden Haydar Dede'nin Kerkük'te bulunan Mevlevihanesi'ne gelip-giden dervişlerin çok olması nedeniyle tahsis edilen 250 kuruş maaş yetersiz gelmiştir. Bu maaşın artırılması hakkında Musul Vilâyeti'nden gelen 1 Ekim 1894 tarihli yazı ekleriyle birlikte Sadaret'e takdim edilmiştir ${ }^{131}$.

Kerkük Mevlevi Şeyhi Haydar Efendi Dâhiliye Nezâreti’ne bir dilekçe göndererek Kerkük’te Mevlevî dergâhı tesis ve fukara ve dervişleri yedirip içirmesi hususunda göstermiş olduğu başarıdan bahsederek kendisine münasib bir nişan verilmesi talebinde bulunmuştur. Bunun üzerine, Dâhiliye Mektubi Kalemi'nden Sadaret'e gönderilen 4 Mayıs 1895 tarihli yazı ile Haydar Efendi'ye beşinci rütbeden bir Mecidî Nişânı ile taltif edilmesine müsaade edilmesi talep edilmiştir ${ }^{132}$.

Kerkük Mevlevi Şeyhi Seyyid Abdullah Dede Efendi, babası Seyyid Mehmed Vehbi Efendi ile birlikte memleketine döneceğini belirterek bir tavsiye yazısı talebinde bulunmuş ve bunun üzerine Musul Valiliği'ne bir yazı yazılmasına dair 27 Nisan 1901 tarihli irade çıkmıştır ${ }^{133}$. Daha sonra Dâhiliye Mektûbî Kalemi'nden Musul Vilâyeti'ne gönderilen 30 Nisan 1901 tarihli yazı ile bu talep dile getirilerek usul ve nizama uygun olarak yapılacak müracaat durumunda gerekli kolaylık

126 COA. DH.MKT., 269/25/1-2.

127 COA. DH.MKT., 269/25/3.

128 COA. DH.MKT., 269/25/4.

129 COA. DH.MKT., 269/25/5.

130 COA. DH.MKT., 269/25/6.

131 COA. DH.MKT., 363/55/1.

132 COA. DH.MKT., 370/77/1.

133 COA. DH.MKT., 2477/58/1. 
ve yardımın yapılması istenmiştir ${ }^{134}$.

\section{Humus Mevlevihanesi}

Osmanlı arşiv belgelerinde ulaştığımız bilgilere göre XIX. yüzyılın ortalarında Humusta bir Mevlevihanenin olduğu ve muhtelif sıkıntıların yaşanması nedeniyle devlet merkezinden yardım almak için birtakım girişimlerde bulunulduğu ortaya çıkmaktadır. 14 Aralık 1853 tarihli Sadaret Mektûbi Kalemi'nden Mâliye Nezâreti'ne gönderilen bir yazıda belirtildiğine göre, Humus'ta bulunan Mevlevihane postnişini Yusuf Efendi, yiyecek masraflarının karşılanmasına dair görüşmeler yapmak üzere İstanbul'a gelmiş ve geriye dönmek için harcırah olmak üzere bir miktar para verilmesi için Meclis-i Vâlâ'ya müracaat etmiştir. Meclis-i Vâlâ bu talebi Sadaret'e ve Sadaret de gereğinin yapılması talebiyle Mâliye Nezâreti'ne havale etmiştir ${ }^{135}$. Bundan yaklaşı1k olarak bir yıl sonra bu defa Konya postnişini Çelebi Efendi, Humus'ta bulunan Mevlevi Zâviyesi'nin şeyh ve dervişlerinin içerisinde bulundukları zaruret ve sıkıntıları tafsilatıyla anlatan ve aynı zamanda yiyecek ve aylık tahsisine dair Meclis-i Vâlâ'ya bir yazı göndermiştir. Veclis-i Vâlâ bu yazıyı Sadaret'e, Sadaret de gereğinin bildirilmesi talebiyle Mâliye Nezâreti'ne havale etmiştir (1854) ${ }^{136}$.

Humus'taki Halid bin Velid kabrinin bulunduğu makamında da Mevlevi Şeyhi Ahmet Efendi tarafından zikir yapıldığı anlaşılmaktadır. Şeyh Ahmet Efendi'ye Halid bin Velid Vakfi'ndan 1288 (1871-1872) tarihinden Ağustos 1900 senesine kadar kayıtsız bir şekilde verilmekte olan beş şinik buğdayın değeri olan 650 kuruşun gelecek 1319 (1901-1902) senesi bütçesine dahil edilmesi için Evkâf-1 Hümâyûn Nezâreti'nden Şûrâ-yı Devlet'e gönderilen 15 Temmuz 1902 tarihli yazı Şûrâ-y1 Devlet Dâhiliye Dairesi'nde görüşülmüştür. Şeyh Ahmet Efendi’ye buğday verilmesi esasen vâk1fin şartlarında olup olmadığı ve olmadığı halde ne zamandan beri, ne gibi bir emir ve karara dayalı olarak verilegeldiği sorulmuştur. 5 Eylül 1902 tarihli gelen cevapta verilen buğdayın vâkıfın şartında olmadığı, hazinede kaydının bulunmadığ 1 ve aynı zamanda bu hususta bir emrin de olmadığ1 bildirilmiştir. Vakfın geliri almasından önce, mahallince tahsis olunarak 1288 (1871-1872) tarihinden beri teâmülen verilegeldiği bildirilmiştir. Bunun üzerine teâmülün vâkıfın şartları yerine geçemeyeceği ve Hazîne-i Evkâf-1 Hümâyûn'da da kaydının bulunmaması yönüyle söz konusu buğdayın tahsisi ile değerinin bütçeye dahil edilmesinin söz konusu olamayacağ 1 ve ayrıca vâkıfın şartına dahil olmaması ve Evkâf-1 Hümâyûn Hazinesi'nden de izin bulunmaması dolayısıyla yapılan uygulamanın usulsüz olduğu ifade edilmiştir. Bundan sonra bu türden bir duruma ihtiyaç kalmaması ve uygunsuzluğun ortaya çıkmaması için söz konusu uygulamaya sebep olanların ortaya çıkarılması hakkında gerekli takibatın yapılmasının Evkâf-1 Hümâyûn Nezâreti’ne havale edilmesi kararı alınmıştır (14 Ekim 1902) ${ }^{137}$. Bu karar bir mazbata halinde Şûrâ-yı Devlet Mâliye Dâiresi'nden Sadaret'e bildirilmiştir. Sadaret de 18 Ekim 1902 tarihli bir yazı ile durumu Evkâf-1 Hümâyûn Nezâreti'ne bildirerek gereğinin yapılmasını istemiştir ${ }^{138}$. Gölpınarlı bu Mevlevihane için, 'Küçük bir zaviyedir. Şeyhi, Kâdirî Tarikatı'na mensup Humus'lu bir zattır. Zaviye, Mevlevilerin elinden çıkmıştır” şeklinde bilgi vermektedir ${ }^{139}$.

134 COA. DH.MKT., 2478/39/1.

135 COA. A.MKT.NZD., 104/89.

136 COA. A.MKT.NZD., 117/67.

137 COA. BEO., 1937/145218/2.

138 COA.BEO., 1937/145218/1.

139 Gölpınarlı, Mevlevîlik, 364. 


\section{Bağdad Mevlevihanesi}

Şia mezhebi etkisiyle Mevlânâ düşüncesi Irakıta Suriyède olduğu kadar yayılma imkanı bulamamıştır ${ }^{140}$. Bununla birlikte bazı şehirlerde Mevlevihaneler vardı. Bunlardan Bağdat Mevlevihanesi Dicle köprüsü üzerinde bulunmaktaydı. Beğlerbeği Çı̆̆ala-zade Yusuf Sinan Paşa'nın himayesi ile Cünûnî Mehmed Dede (öl. 1620) tarafından yeniden kurulmuştur. Bağdat'ta bulunan küçük, mütevazi tekke onun tarafından tam teşkilatlı bir Mevlevihane haline getirilmiş$\operatorname{tir}^{141}$.

Bu Mevlevihanenin XX. yüzyılın başlarında cami haline getirildiği anlaşılmaktadır. Bağdat Mevlevi şeyhi Şemseddin Efendi Sadârete yazdığı bir arzuhal ile Bağdat'ta bulunan Mevlevi tarikatına ait dergâhın şeklinin değiştirilerek cami haline getirildiğini ifade ederek asli haline dönüştürülmesini talep etmiştir. Bu arzuhal, 1 Mart 1906 tarihli yazı ile Sadaret'ten Evkâf-ı Hümâyûn Nezâreti'ne havale edilmiş ve gereğinin yapılması istenmiştir ${ }^{142}$.

\section{Beyrut Mevlevihanesi}

XIX. yüzyılın sonlarında Beyrut'ta bir Mevlevihane açılmasına ilişkin girişimde bulunulmuştur. Mevlevi tarikatından Mehmet Arif Efendi bir arzuhal sunarak, Beyrut'ta Mevlevi usulü üzerine zikir ve dua okumak için bir yer olmadığı ve "Re's-i Beyrut" "Beyrut Başı" tarafında bulunan caminin Mevlevî derviş ve müridlerinin ikamet ve ibadetine tahsis olunur ise orada gece ve gündüz dua ve zikir ile Hazret-i Mevlânâ'nın öğretilerinin okunabileceğini ifade etmiştir. Aynı zamanda, gereğinin yapılması talebiyle Beyrut Vilayeti İdare Meclisi'ne müracaatta bulunmuştur. Bu husus Beyrut Vilâyeti İdâre Meclisi'nde görüşülerek alınan karar 20 Aralık 1894 tarihli yazı ile Sadaret'e gönderilmiştir. Bu karara göre, Osmanlı Devleti'nin her tarafında olduğu gibi Suriye bölgesinde de Şam, Halep, Trablus, Lazkıye ve benzeri şehir ve kasabalarda mamur ve muntazam Mevlevi dergâhları bulunmaktadır. Beyrut Şehri de Suriye'nin başlıca iskelelerinden olması nedeniyle gelip-giden Mevlevi dedeleri eksik olmamaktadır. Buna karşılık söz konusu şehirde Mevlevi dede ve müritlerinin ikamet edip geceleyebilecekleri bir dergâh ve yer bulunmamaktadır. Bu sebeple Beyrut'a geldiklerinde han köşelerinde yatıp-kalkmak mecburiyetinde kalmaktadırlar. Söz konusu sıkıntıyı bertaraf etmek üzere Beyrut Şehri'nde de münasip bir yerde bir Mevlevi dergâhının yapılması için gerekli işlemlerin yapılmasına müsaade edilmesi arz edilmiştir ${ }^{143}$.

Mevlevi dedelerinden Arif Efendi'nin talebi üzerine bu husustaki 20 Aralık 1894 tarihli mazbata Vilayet İdare Meclisi'nden Sadarete arz edilmiş olmasına rağmen bir cevap alınamamıştır. Arif Efendi'nin yeniden müracaatta bulunması üzerine Beyrut Vilâyeti'nden Beyrut Valisi imzasıyla Sadarete 24 Haziran 1895 tarihinde yeni bir yazı gönderilerek gereğinin yapılmasına müsaade buyrulması talebinde bulunulmuştur ${ }^{144}$. Beyrut Vilâyeti İdâre Meclisi'nden Sadârete gelen 20 Aralık 1894 tarihli mazbata, gereğinin yapılması talebiyle 10 Ocak 1895 tarihli bir yazı ile Evkâf-1 Hümâyûn Nezâreti'ne havale edilmiştir ${ }^{145}$.

Evkâf-1 Hümâyûn Nezâreti'nden Sadârete gönderilen 23 Temmuz 1895 tarihli cevabi yazıda, Mevlevihane inşasına dair taleple ilgili olarak, bir Mevlevihane yapımı için Evkâf-1 Hümâyûn bütçesinde bir karşılık olmadığı ifade edilmiştir. Aynı zamanda, herhangi bir vakıf gelirinden vakfiye

140 Ürün, “Mevlevihaneler”, 450.

141 Kraiser, "Mevlevihaneler", 110.

142 COA. BEO., 2771/207781.

143 COA. BEO., 549/41118/4.

144 COA. BEO., 549/41118/3.

145 COA. BEO., 549/41118/1. 
şartları haricinde bir yere para sarf edilmesinin mümkün olmadığı ve mahallince de söz konusu inşaat için bir karşılık gösterilmemiş olduğu ifade edilerek ilgili evrak geriye iade edilmiştir ${ }^{146}$.

\section{Sonuç}

Mevlevilik, Mevlânâ Celâleddîn-i Rûmî’nin fikirleri ve öğretileri etrafinda şekillenen ve Anadolu'da XIII. yüzyılda ortaya çıkmış bir tarikattır. Mevlevilik, Anadolu'da, Balkanlarda ve Arap coğrafyasında önemli ölçüde yayılmıştır. Özellikle XVI. yüzyıldan itibaren Arap coğrafyasında yayılmaya başlamış ve muhtelif yerlerde Mevlevihaneler açılmıştır. Arap coğrafyasında, Mevleviliğin özellikle Suriye bölgesinde daha etkili olduğunu söylemek mümkündür. Arap coğrafyasında pek çok Mevlevi tekkesi ve zaviyesi bulunmasına karşılık bunların önde gelenleri olarak Halep, Şam, Kahire, Mekke, Medine, Kudüs, Trablusşam, Kerkük, Humus, Bağdad ve Beyrut Mevlevihaneleri sayılabilir. Bu Mevlevihaneler içerisinde Halep Mevlevihanesinin ayrı bir yeri olduğu da muhakkaktır. Bilhassa Türkiye'de Tekke ve Zaviyelerin kapatılması kanunundan sonraki dönemde Çelebilik makamı Halep'te oluşturulmasıyla birlikte söz konusu Mevlevihane yeni bir misyon yüklenmiştir.

\section{Kaynakça}

\section{Arşiv Kaynakları}

Cumhurbaşkanlığı Devlet Arşivleri Başkanlığı Osmanlı Arşivi (COA.) A.DVN., 79/20.

COA. A.MKT.DV., 142/96/1, 2.

COA. A.MKT.MHM., 196/67; 130/27; 201/6; 231/53.

COA. A.MKT.NZD., 104/89; 117/67.

COA. A.MKT.UM., 104/44; 110/68/1, 2; 354/80/2; 437/62/1,2.

COA. BEO., 1480/110958/3，4; 1531/114803; 1577/118249; 1937/145218/1， 2; 2771/207781; 3879/290921; 549/41118/1, 2, 3, 4; 1455/109120; 2183/163680; 2238/167785; 2661/199514/1, 2, 3,4, 5; 2702/202594; 2735/205090; 2739/205354; 2753/206453; 2775/208100; 2919/218872; 2925/219348; 2982/223641/1, 2, 3, 4, 5; 3875/290578; 437/32729; 486/36424/1, 2 , 3,$4 ; 927 / 69508 / 1,2$.

COA. C.DH., 7/312.

COA. DH.KMS.,40/5, 7, 9-11, 13, 15, 16, 18, 24, 54, 57, 60, 65, 67, 72, 74, 79-94, 99, 103, 101.

COA. DH.MKT., 2131/15; 2198/93; 2352/31, 2458/25; 2477/58/1; 2478/39/1; 269/25/1, 2, $3,4,5,6 ; 363 / 55 / 1 ; 370 / 77 / 1 ; 2149 / 65 ; 258 / 45 / 1,2,3 ; 778 / 48 / 1$;

COA. İ.DH., 78/3887/1, 2; 1011/79849; 1268/99658.

COA. İ.ML., 15/40.

COA. İE.EV., 26/3092.

COA. ŞD., 100/45/1, 7, 11. 


\section{Araştırma ve İncelemeler} 1983.

Gölpınarlı, Abdülbaki. Mevlânâ'dan Sonra Mevlevîlik. İstanbul: İnkılap ve Aka Kitapevleri,

Güler, Mustafa. "XVIII. Yüzyılın Sonunda Mukaddes Şehirlerde Yaşayan Mevleviler". Sultan Dîvânî ve Mevlevîlik I içerisinde, ed. Mustafa Karazeybek, 75-85. Afyonkarahisar: Afyon Kocatepe Üniversitesi Eğitim Sağlık ve Bilimsel Araştırma Vakfı, 2015.

Güneş, Hasan Hüseyin ve Mehtap Kuş. "Kudüs Mevlevihanesi ve Vakfiyeleri üzerine Metodik Bir İrdeleme”. 2. Uluslar arası Sultan Dîvânî ve Mevlevîlik Sempozyumu 1-2 Haziran 2012 Bildiriler içerisinde, ed. Mustafa Oner Uzun, 118-26, Afyonkarahisar: Afyon Kocatepe Üniversitesi, 2013.

Kraiser, Klaus. "Evliya Çelebi ve Başka Kaynaklara Göre Arap Âleminin Doğusundaki Büyük Şehirlerde Mevlevihaneler”. Çev: Semih Tezcan, Osmanlı Araştırmaları 14, (1994): 101-115.

Küçük, Sezai. "Halep Mevlevihanesi”. İLAM Araştırma Dergisi 3, sy 2 (Temmuz-Aralık 1998): 73106.

Küçük, Sezai. Mevleviliğin Son Yüzyılı. İstanbul: Vefa Yayınlar, 2007.

Küçükkaya, M. Askeri. “Evliya Çelebi Seyahatnamesi’nde Ad1 Geçen Mevlevihane ve Tekkeler”. Harran Üniversitesi Illahiyat Fakültesi Dergisi 18, (Temmuz-Aralık 2007): 177-186.

Önder, Mehmet. «Konya'da Mevlânâ Dergâhı Merkez Arşivi ve Mevlevihaneler”. Osmanlı Araştırmaları 14, (1994): 137-142.

Özönder, Hasan. "Mevleviliğin Mısır'daki Temsilciliği: Kahire Mevlevî-hânesi”. II. Milletlerarası Mevlânâ Kongresi (3-5 Mayls 1990) içerisinde, 175-94, Konya: Selçuk Üniversitesi, 1991.

Şafak, Yakup. «Konya Mevlâna Dergâhı Son Aşçıbaşısı Nizameddin Çelebi». Curr Res Soc Sci 3, sy 2 (2017): 71-75.

Tadmori, Khaled. “Trablusşam Mevlevihanesi'nin Mimarisi ve Restorasyon Projesi”. Uluslararası Mevlânâ Sempozyumu 8-12 Mayls 2007 İstanbul-Konya Bildirileri 2 içerisinde, ed. Mahmut Erol Kılıç, Celil Güngör, Mustafa Çiçekler, 851-870, İstanbul: Motto Project, 2010.

Tanrıkorur, Barihüda. "Mısır Mevlevihanesi”. DİA 29 içerisinde, 586-88, Ankara: Türkiye Diyanet Vakfi, 2004.

Ürün, Ahmet Kazım. «Ortadoğu'da Mevlâna ve Mevlevihaneler”, Uluslararası Sempozyum Dünyada Mevlâna İzleri, 13-15 Aralık 2007 Bildiriler içerisinde, Yayın ve Düzelti Kurulu: Nuri Şimşekler vd., 447-54, Konya: SÜMAM Yayınları, 2010.

Yazıc1, Gülgün. "Gelibolu-Kahire-İstanbul Üçgeninde Bir Mevlevi Şeyhi ve Oğulları”. Divan Edebiyatı Araştırmaları Dergisi 2, (2009): 207-222. 


\section{Ekler:}

Ek.1: Kerkük Mevlevihanesi Postnişini Haydar Mevlevi Efendi'ye Maaş Bağlanmasına dair İrade-i Seniyye (COA. İ.DH., 1268/99658)

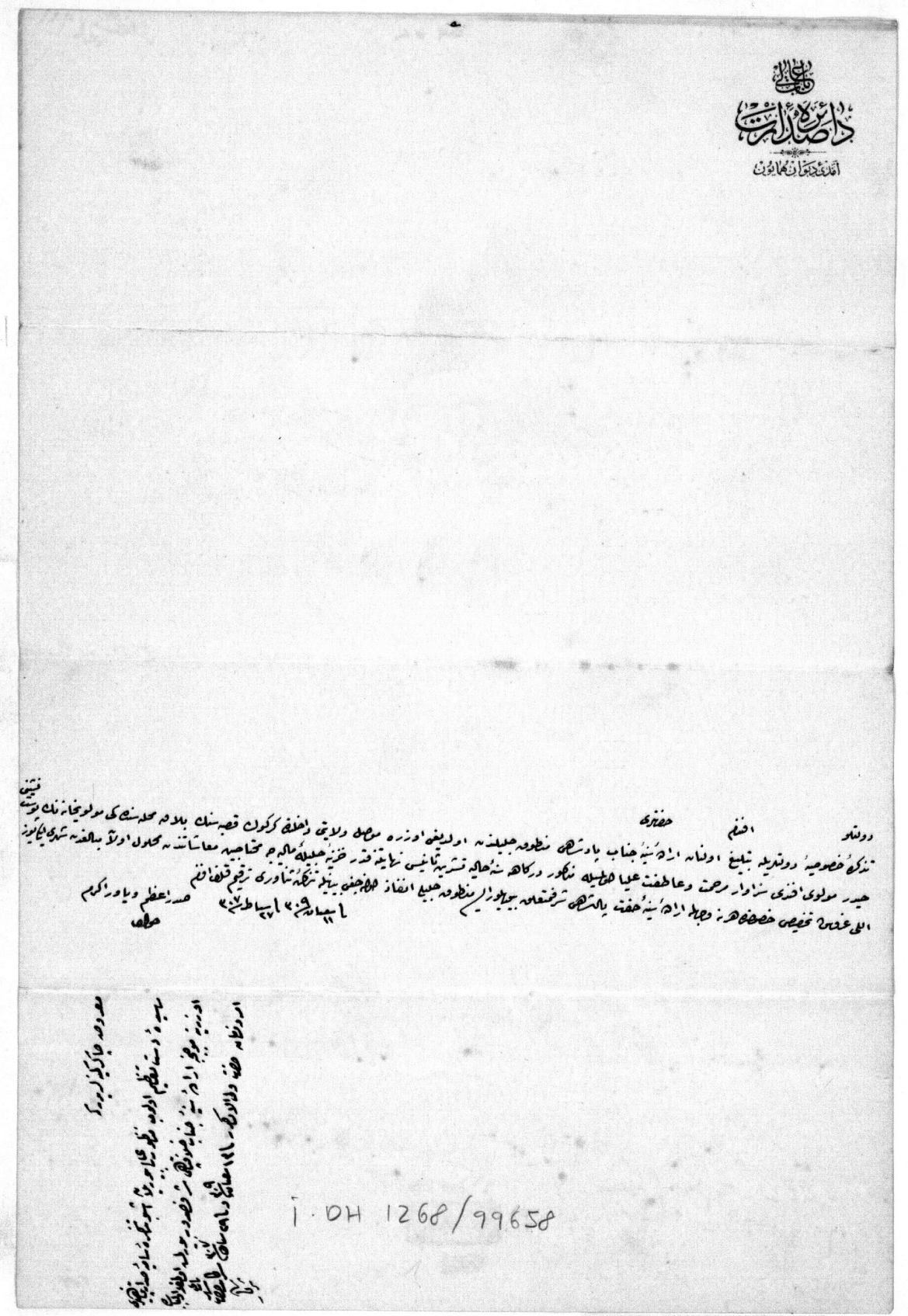

I.DH.01268 
Ek.2: Mekke Mevlevihanesi Şeyhinin Beratının Yenilenmesine İlişkin Arzuhal (COA. İE.EV., 26/3092)

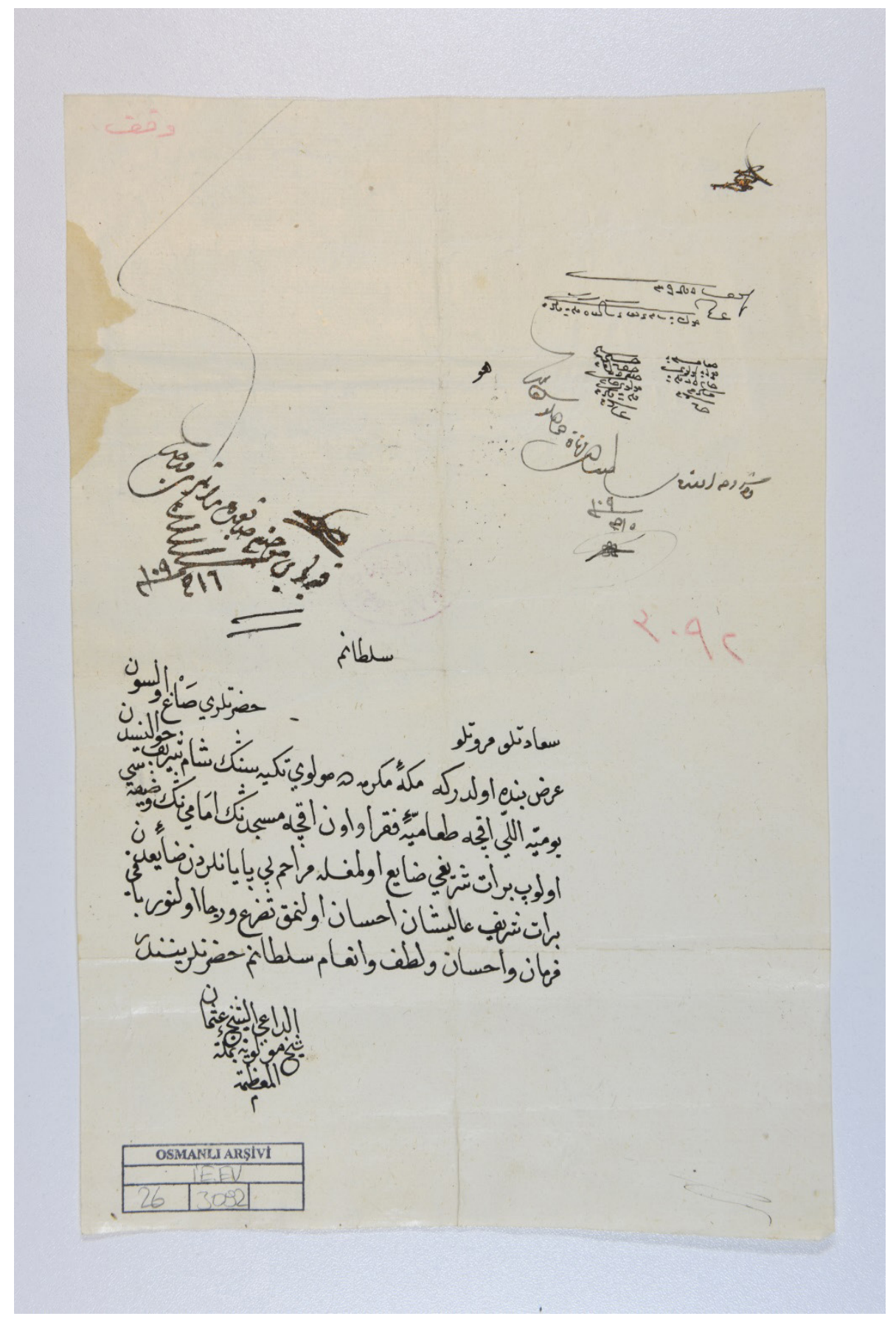

